\title{
Environmental properties of phosphonium, imidazolium and ammonium cation-based ionic liquids as potential lubricant additives
}

\author{
P. Oulego ${ }^{\mathrm{a}}$, D. Blanco ${ }^{\mathrm{b} *}$, D. Ramos ${ }^{\mathrm{b}}$, J.L. Viesca ${ }^{\mathrm{b}, \mathrm{c}}$ \\ M. Díaz ${ }^{a}$ A. Hernández Battez ${ }^{b, c}$ \\ a Department of Chemical and Environmental Engineering, University of Oviedo, Asturias, Spain \\ ${ }^{\mathrm{b}}$ Department of Construction and Manufacturing Engineering, University of Oviedo, Asturias, Spain \\ ${ }^{c}$ Department of Design and Engineering, Bournemouth University, Poole, BH12 5BB \\ ${ }^{(*)}$ Email: blancoadavid@uniovi.es
}

\begin{abstract}
This research compares the environmental properties (bacterial toxicity and biodegradability) of 12 ionic liquids -ILs- ( 7 phosphonium, 2 imidazolium and 3 ammonium cation-based ones), potentially applicable as lubricant additive, with two types of the traditional lubricant additive ZDDP. Aquatic toxicity was determined by means of Vibrio fischeri and Escherichia coli bacteria, while biodegradability was evaluated through biological oxygen demand $\left(\mathrm{BOD}_{5}\right)$ and chemical oxygen demand $(\mathrm{COD})$ measurements. Regarding toxicity results, $\left[\mathrm{P}_{4442}\right][\mathrm{DEP}]$ was the least toxic IL (acute 3 according to GHS) for both bacteria, whereas ZDDP fell into the acute 1 category (very toxic). All samples tested turned out to be poorly biodegradable, showing $\mathrm{BOD}_{5} / \mathrm{COD}$ values below 0.1 . Two ILs showed better combined tribological and environmental properties than ZDDP.
\end{abstract}

Keywords: ionic liquids, lubricant additive, bacterial toxicity, biodegradability

\section{Introduction}

Industry is constantly developing new manufacturing processes to improve speed, efficiency and other parameters. In addition, minimizing environmental risks and contributing to sustainable development in agreement with the ideals of green chemistry are also important objectives during the design and optimization of any industrial process [1]. This is partly because the increasing awareness of the environmental impact of the chemical industry has led to a more restrictive legislation in this field [2].

ILs are molten salts, thermally stable, which melt under $100{ }^{\circ} \mathrm{C}$. In addition, their useful physical and chemical properties (non-flammability, low vapour pressure, remarkable thermal and oxidative stability, ashless character, etc.) is the reason why their applications are rapidly growing in number [3-8]. Although these compounds have long been thought of as "green solvents" [9], there is an urgent necessity to explore and identify their effect on living beings in order to avoid negative consequences after unintentional exposure [10]. Research papers dealing with the environmental impact of ILs have become more numerous recently, although our understanding of the biodegradability and toxicity for ecosystems of most ILs is still limited [11- 
19]. Nowadays, the environmental legislation of the EU is mainly focused on the safety of chemicals, an objective that clearly requires ecotoxicological and biodegradation data [20].

Using ILs in lubrication has been a promising option since 2001 [21-26]. These melting salts have excellent properties, which are desirable for their utilization as either lubricant base stock or lubricant additives. Research using ILs as neat lubricants has been conducted with different tribological contacts: steel-aluminium $[27,28]$, steel-cast iron [29], steel-steel [30-37], and even with coatings [38-42]. The current high cost of ILs means that although they may well be employed in systems under extreme conditions $[43,44]$ at which conventional lubricants fail (aerospace and spacecraft applications), they are often too expensive to use under less severe conditions in which other products perform adequately. This is why much research focuses on their use as a lubricant additive in order to enhance their cost effectiveness [26]. Moreover, the solubility problems of ILs in common non-polar oils have tended to direct research towards their utilization as additives at low concentrations in these base stocks $[29,39-42,45-50]$ and few studies have tested their use as additive of a non-polar fully-formulated oil [51-53]. Otherwise, various research studies focused on polar oils have used ionic liquids as additive with the aim of overcoming the solubility problem [54-68]. However, the significant amounts of lubricant released into the environment, affecting flora, fauna and, by extension, human life, make it necessary to conduct biodegradability and toxicity studies in order to verify that these recently developed products are environmentally friendly [69-72].

Many of the $12 \mathrm{ILs}$ that have been chosen for testing here $\left(\left[\mathrm{P}_{6,6,6,14}\right]\left[\left(\mathrm{iC}_{8}\right)_{2} \mathrm{PO}_{2}\right],\left[\mathrm{P}_{6,6,6,14}\right][\mathrm{BEHP}]\right.$, $\left[\mathrm{P}_{6,6,6,14}\right][\mathrm{TFSI}], \quad\left[\mathrm{P}_{4,4,4,14}\right][\mathrm{DBS}], \quad\left[\mathrm{P}_{4442}\right][\mathrm{DEP}], \quad\left[\mathrm{P}_{6,6,6,14}\right][\mathrm{DCA}], \quad\left[\mathrm{P}_{6,6,6,14}\right][\mathrm{Cl}], \quad\left[\mathrm{C}_{12} \mathrm{C}_{1} \mathrm{IM}\right][\mathrm{TFSI}]$, $\left[\mathrm{C}_{10} \mathrm{C}_{1} \mathrm{C}_{10} \mathrm{IM}\right][\mathrm{TFSI}]$, [ $\left.\mathrm{N}_{4441}\right][\mathrm{TFSI}]$, [N $\left.\mathrm{N}_{8881}\right][\mathrm{TFSI}]$ and $\left.\left[\mathrm{N}_{4441}\right][\mathrm{DCA}]\right)$ have been previously studied as lubricant additive. The complete names and CAS numbers of the ILs can be found in Table 1. Qu et al. [42, 45], Somers et al. $[25,54]$ and Gonzalez et al. [48] stated that $\left[\mathrm{P}_{6,6,6,14}\right][\mathrm{BEHP}]$ and $\left[\mathrm{P}_{6,6,6,14}\right]\left[\left(\mathrm{iC}_{8}\right)_{2} \mathrm{PO}_{2}\right]$ are completely miscible in a wide variety of oils (synthetic and mineral ones), showing similar tribological characteristics to ZDDP in different contacts (steel-steel, steel-aluminium, steel-cast iron), even outperforming this traditional additive at $100^{\circ} \mathrm{C} .\left[\mathrm{P}_{6,6,6,14}\right][\mathrm{TFSI}]$ was studied as an additive in different types of oils by González et al. [48] and Blanco et al. [66], showing the mixtures exhibited better tribological behaviour in a steel-steel contact than the corresponding base oils. Viesca et al. [73] and Battez et al. [74] proved that the addition of $\left[\mathrm{C}_{12} \mathrm{C}_{1} \mathrm{IM}\right][\mathrm{TFSI}]$ and $\left[\mathrm{N}_{8881}\right][\mathrm{TFSI}]$ to a diester oil showed tribological results 
similar to those of the base oil itself, maybe because of competition between base oil and additive in the contact surface, because of their similar polarity. In addition, Blanco et al. $[75,76]$ studied the tribological performance of $\left[\mathrm{P}_{4,4,4,14}\right][\mathrm{DBS}],\left[\mathrm{P}_{6,6,6,14}\right][\mathrm{TFSI}]$ and $\left[\mathrm{P}_{6,6,6,14}\right][\mathrm{DCA}]$ as additives in a polar oil, finding results suggesting the same competition between the base oil and the ionic liquids mentioned above.

Despite their increasing use, there are just a couple of studies about the environmental properties of ILs synthesized for lubrication purposes [77, 78]; and the importance of extending existing knowledge of the toxicity and biodegradability of ILs has been underlined by Qu et al. [26]. That is the reason why the aim of this research work is to determine the biodegradability and toxicity of the 12 above-mentioned ILs. In order to verify the obtained results, two different samples of the traditional lubricant additive ZDDP: Phosphorodithioic acid, mixed O,O-bis (1,3-dimethylbutyl and iso-Pr) esters, zinc salts) and phosphorodithioic acid, mixed O,O-bis (diisooctyl) esters, zinc salts), named as ZDDP1 and ZDDP2 respectively, were used as comparison samples [79].

\section{Experimental details}

\subsection{Ionic liquids and $Z D D P s$}

Table 1 shows the chemical descriptions of 14 substances selected due to their use or potential use as additive in lubricants, whilst Fig.1 displays their chemical structure. All ILs are commercially available (Ionic Liquid Technologies $\mathrm{GmbH}$ and Sigma-Aldrich S.A.) and Repsol, S.A. kindly supplied both zinc dialkyldithiophosphates (ZDDP).

Table 1. Chemical descriptions of the ILs and ZDDPs.

\begin{tabular}{lcccc}
\hline Abbreviation & IUPAC name & CAS Number & $\begin{array}{c}\text { Purity } \\
\text { (\%) }\end{array}$ & $\begin{array}{c}\text { Molecular } \\
\text { weight }\end{array}$ \\
\hline$\left[\mathrm{P}_{6,6,6,14}\right]\left[\left(\mathrm{iC}_{8}\right)_{2} \mathrm{PO}_{2}\right]$ & $\begin{array}{c}\text { Trihexyltetradecylphosphonium bis(2,4,4- } \\
\text { trimethylpentyl) phosphinate }\end{array}$ & $465527-59-7$ & 90 & 773.3 \\
\hline$\left[\mathrm{P}_{6,6,6,14}\right][\mathrm{BEHP}]$ & $\begin{array}{c}\text { Trihexyltetradecylphosphonium bis(2- } \\
\text { ethylhexyl)phosphate }\end{array}$ & $1092655-30-5$ & 98 & 837.3 \\
\hline$\left[\mathrm{P}_{6,6,6,14}\right][\mathrm{TFSI}]$ & $\begin{array}{c}\text { Trihexyltetradecylphosphonium } \\
\text { bis(trifluoromethylsulfonyl) imide }\end{array}$ & $460092-03-9$ & 98 & 763.2 \\
\hline$\left[\mathrm{P}_{4,4,4,14}\right][\mathrm{DBS}]$ & $\begin{array}{c}\text { Tributyltetradecylphosphonium } \\
\text { dodecylbenzenesulfonate }\end{array}$ & $959685-58-6$ & 95 & 725.3 \\
\hline$\left[\mathrm{P}_{4442}\right][\mathrm{DEP}]$ & Tributylethylphosphonium diethylphosphate & $20445-94-7$ & 95 & 384.5 \\
\hline$\left[\mathrm{P}_{6,6,6,14}\right][\mathrm{DCA}]$ & Trihexyltetradecylphosphonium dicyanamide & $701921-71-3$ & 95 & 549.9 \\
\hline
\end{tabular}




\begin{tabular}{lcccc}
\hline$\left[\mathrm{P}_{6,6,6,14}\right][\mathrm{Cl}]$ & Trihexyltetradecylphosphonium chloride & $258864-54-9$ & 95 & 519.3 \\
\hline$\left[\mathrm{C}_{12} \mathrm{C}_{1} \mathrm{IM}\right][\mathrm{TFSI}]$ & $\begin{array}{c}\text { 1-Dodecyl-3-methylimidazolium } \\
\text { bis(trifluoromethylsulfonyl) imide }\end{array}$ & $404001-48-5$ & 98 & 531.6 \\
\hline$\left[\mathrm{C}_{10} \mathrm{C}_{1} \mathrm{C}_{10} \mathrm{IM}\right][\mathrm{TFSI}]$ & $\begin{array}{c}\text { 1,3-Didecyl-2-methylimidazolium } \\
\text { bis(trifluoromethylsulfonyl) imide }\end{array}$ & - & 95 & 643.8 \\
\hline$\left[\mathrm{N}_{4441}\right][\mathrm{TFSI}]$ & $\begin{array}{c}\text { Tributylmethylammonium } \\
\text { bis(trifluoromethylsulfonyl) imide }\end{array}$ & $405514-94-5$ & 99 & 480.5 \\
\hline$\left[\mathrm{N}_{8881}\right][\mathrm{TFSI}]$ & $\begin{array}{c}\text { Methyl-trioctylammonium } \\
\text { bis(trifluoromethylsulfonyl)imide }\end{array}$ & $375395-33-8$ & 99 & 648.8 \\
\hline$\left[\mathrm{N}_{4441}\right][\mathrm{DCA}]$ & Tributylmethylammonium dicyanamide & $1262230-03-4$ & 95 & 252.0 \\
\hline ZDDP1 & $\begin{array}{c}\text { Phosphorodithioic acid, mixed O,O-bis (1,3- } \\
\text { dimethylbutyl and iso-Pr) esters, zinc salts }\end{array}$ & $84605-29-8$ & - & 576.0 \\
\hline ZDDP2 & $\begin{array}{c}\text { Phosphorodithioic acid, mixed O,O-bis } \\
\text { (diisooctyl) esters, zinc salts }\end{array}$ & $28629-66-5$ & - & 772.5 \\
\hline
\end{tabular}

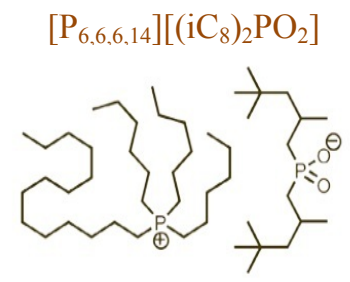

$\left[\mathrm{P}_{4,4,4,14][\mathrm{DBS}]}\right.$
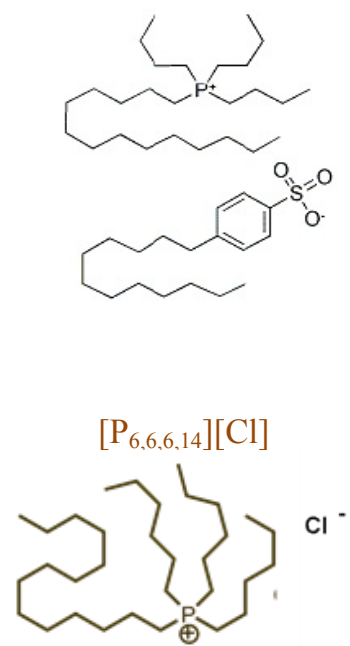

$\left[\mathrm{N}_{4441}\right][\mathrm{TFSI}]$<smiles>CCCC[N+](C)(CCCC)CCCC</smiles>

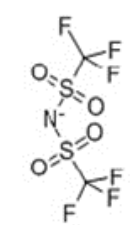

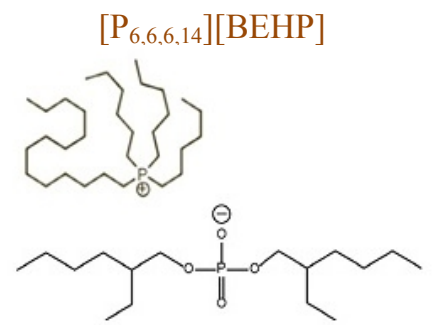

$\left[\mathrm{P}_{4442}\right][\mathrm{DEP}]$<smiles>CCCCC(CCCC)(CCCC)CCCC</smiles><smiles>CCOP(=O)([O-])OCC</smiles>

$\left[\mathrm{C}_{12} \mathrm{C}_{1} \mathrm{IM}\right][\mathrm{TFSI}]$<smiles></smiles>

$\left[\mathrm{N}_{8881}\right][\mathrm{TFSI}]$

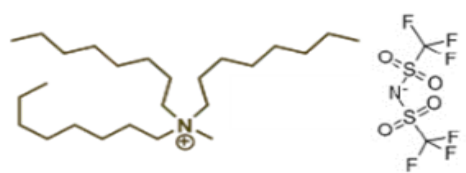

$\left[\mathrm{P}_{6,6,6,14}\right][\mathrm{TFSI}]$

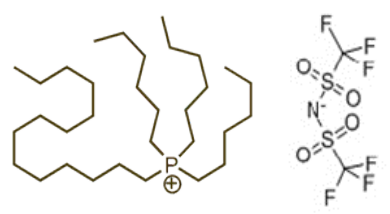

$\left[\mathrm{P}_{6,6,6,14}\right][\mathrm{DCA}]$

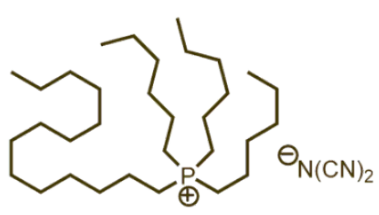

$\left[\mathrm{C}_{10} \mathrm{C}_{1} \mathrm{C}_{10} \mathrm{IM}\right][\mathrm{TFSI}]$

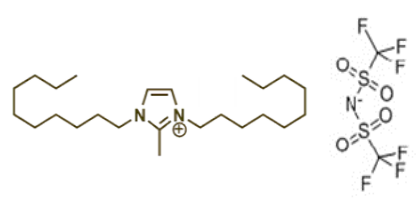

[ $\left.\mathrm{N}_{4441}\right][\mathrm{DCA}]$<smiles>CCCC[N+](C)(CCCC)CCCC</smiles> 
$\mathrm{Zn}^{2+}$

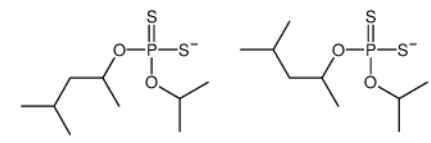

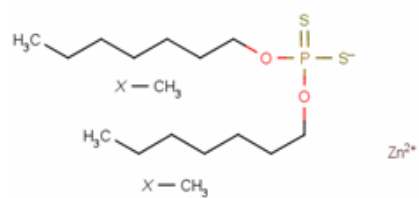

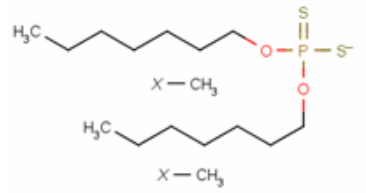

Fig. 1. Chemical structures and abbreviation of the ILs and ZDDPs.

\subsection{Preparation of the water solutions of ILs}

The aqueous solutions were obtained by mixing $1 \mathrm{~g}$ of each substance to $2 \mathrm{~g}$ of distilled water and the resulting samples were then gently stirred for 1 minute in a vortex mixer and centrifuged (5000 rpm, 3 minutes). Phase separation was clearly observed in all cases, except for $\left[\mathrm{P}_{4442}\right][\mathrm{DEP}]$, where separation was minimal. The minority phase (additive) was discarded and the main phase (aqueous) was used to prepare the stock solutions that were to be employed in the determination of bacterial toxicity and biodegradability. After a visual inspection, it could be seen that $\left[\mathrm{P}_{4442}\right][\mathrm{DEP}],\left[\mathrm{N}_{4441}\right][\mathrm{DCA}]$ and $\left[\mathrm{P}_{4,4,4,14}\right][\mathrm{DBS}]$, were soluble and the remaining ILs were partially soluble. In order to determine the additive concentrations (Table 2), total organic carbon (TOC) of the main phase was calculated with a Shimadzu TOC- $\mathrm{V}_{\mathrm{CSH}}$ analyser. These concentrations were determined basing on the TOC data, the number of carbon atoms and the molecular weight of each of the ILs (see Table 1) according to eq. (1):

$$
I L_{\text {conc }}(g / L)=T O C_{\text {conc }}(g C / L) \times \frac{1 m o l-g C}{12 g C} \times \frac{1 m o l-g I L}{n m o l-g C} \times \frac{I L_{M W}}{1 m o l-g I L}
$$

where: $\mathrm{IL}_{\text {conc }}$ is the $\mathrm{IL}$ concentration, $\mathrm{TOC}_{\text {conc }}$ is the TOC concentration, $\mathrm{n}$ is the number of carbon atoms of the IL and $\mathrm{IL}_{\mathrm{MW}}$ is the molecular weight of the IL.

Once the concentration of the IL was known, the stock solution used in the bacterial toxicity and biodegradability tests $(0.1 \mathrm{~g} / \mathrm{L}$ and $1 \mathrm{~g} / \mathrm{L})$ was prepared by dilution of the former in distilled water. 
Table 2. Solubility data, TOC and IL concentrations of the different ILs and ZDDPs studied.

\begin{tabular}{llll}
\hline Sample & $\begin{array}{l}\text { Solubility at } \mathbf{2 0}^{\mathbf{o}} \mathbf{C} \\
\left.\mathbf{( g ~ o f ~} \mathbf{I L} / \mathbf{m L} \text { of } \mathbf{H}_{\mathbf{2}} \mathbf{O}\right)\end{array}$ & $\begin{array}{l}\text { TOC concentration } \\
(\mathbf{g ~ C} / \mathbf{L})\end{array}$ & $\begin{array}{l}\text { IL concentration } \\
\mathbf{( g / \mathbf { L } )}\end{array}$ \\
\hline$\left[\mathrm{P}_{6,6,6,14}\right]\left[\left(\mathrm{iC}_{8}\right)_{2} \mathrm{PO}_{2}\right]$ & $2.1 \cdot 10^{-3} \pm 1 \cdot 10^{-4}$ & $1.03 \pm 0.03$ & $1.39 \pm 0.04$ \\
{$\left[\mathrm{P}_{6,6,6,14}\right][\mathrm{BEHP}]$} & $5.8 \cdot 10^{-3} \pm 3 \cdot 10^{-4}$ & $2.7 \pm 0.1$ & $3.9 \pm 0.1$ \\
{$\left[\mathrm{P}_{6,6,6,14}\right][\mathrm{TFSI}]$} & $5.8 \cdot 10^{-4} \pm 2 \cdot 10^{-5}$ & $0.206 \pm 0.002$ & $0.385 \pm 0.003$ \\
{$\left[\mathrm{P}_{6,6,6,14}\right][\mathrm{DCA}]$} & $7.0 \cdot 10^{-4} \pm 1 \cdot 10^{-5}$ & $0.355 \pm 0.001$ & $0.479 \pm 0.001$ \\
{$\left[\mathrm{P}_{6,6,6,14}\right][\mathrm{Cl}]$} & $2.3 \cdot 10^{-3} \pm 3 \cdot 10^{-4}$ & $1.14 \pm 0.03$ & $1.54 \pm 0.04$ \\
{$\left[\mathrm{P}_{4,4,4,14}\right][\mathrm{DBS}]$} & $4.3 \cdot 10^{-2} \pm 5 \cdot 10^{-3}$ & $21.0 \pm 0.3$ & $28.9 \pm 0.4$ \\
{$\left[\mathrm{P}_{4442}\right][\mathrm{DEP}]$} & $4.8 \cdot 10^{-1} \pm 4 \cdot 10^{-2}$ & $179.8 \pm 0.7$ & $320 \pm 1$ \\
{$\left[\mathrm{C}_{12} \mathrm{C}_{1} \mathrm{IM}\right][\mathrm{TFSI}]$} & $7.0 \cdot 10^{-4} \pm 1 \cdot 10^{-5}$ & $0.189 \pm 0.008$ & $0.46 \pm 0.02$ \\
{$\left[\mathrm{C}_{10} \mathrm{C}_{1} \mathrm{C}_{10} \mathrm{IM}\right][\mathrm{TFSI}]$} & $3.0 \cdot 10^{-4} \pm 1 \cdot 10^{-5}$ & $0.10 \pm 0.01$ & $0.22 \pm 0.02$ \\
{$\left[\mathrm{~N}_{8881}\right][\mathrm{TFSI}]$} & $1.5 \cdot 10^{-4} \pm 2 \cdot 10^{-5}$ & $0.0515 \pm 0.0001$ & $0.1032 \pm 0.0001$ \\
{$\left[\mathrm{~N}_{4441}\right][\mathrm{TFSI}]$} & $1.7 \cdot 10^{-3} \pm 2 \cdot 10^{-4}$ & $0.421 \pm 0.002$ & $1.123 \pm 0.005$ \\
{$\left[\mathrm{~N}_{4441}\right][\mathrm{DCA}]$} & $1.2 \cdot 10^{-1} \pm 3 \cdot 10^{-2}$ & $58.5 \pm 0.7$ & $81.9 \pm 0.9$ \\
$\mathrm{ZDDP} 1$ & $3.0 \cdot 10^{-3} \pm 4 \cdot 10^{-4}$ & $0.76 \pm 0.01$ & $2.03 \pm 0.03$ \\
$\mathrm{ZDDP} 2$ & $4.9 \cdot 10^{-3} \pm 2 \cdot 10^{-4}$ & $1.66 \pm 0.03$ & $3.35 \pm 0.07$ \\
\hline
\end{tabular}

\subsection{Biodegradability: chemical and biochemical oxygen demand}

The dichromate methodology at $600 \mathrm{~nm}$ was used to determine the chemical oxygen demand (COD), employing a Hach DR/2500 spectrophotometer [80]. In addition, a respirometric method was employed for measuring the biological oxygen demand $\left(\mathrm{BOD}_{5}\right)$ by means of Lovibond BOD system. Solutions containing $0.1 \mathrm{~g} / \mathrm{L}$ of each additive were prepared and the $\mathrm{pH}$ was adjusted until it was within the range of $6.5-7$ using a Jenway $3510 \mathrm{pH}$-meter. Sodium acetate solution $(0.1 \mathrm{~g} / \mathrm{L})$ was used as the control sample (free of toxicants). Finally, the effluent from an aerobic bioreactor $(1 \mathrm{~mL})$ was employed to inoculate $157 \mathrm{~mL}$ of each sample solution and then, after a mixing step, poured into the BOD bottles and incubated at $20^{\circ} \mathrm{C}$ for 5 days (dark conditions). All analytical measurements were repeated at least three times.

\subsection{Toxicity assays}

\subsubsection{Vibrio fischeri tests}

Bacterial toxicity assessment was conducted with Vibrio fischeri. This bioluminescence assay is a European standard ecotoxicological test (DIN EN ISO 11348) [81] and one of the methods most widely applied to appraise the potential environmental risk of a compound in aquatic environments, since it is cost-effective, rapid and well-established [82]. The Biofix ${ }^{\circledR}$ Lumi-10 commercial test was used with a specially selected 
lyophilized strain (NRRL number B-11177) and the bacterial toxicity was determined in serial two-fold aqueous dilutions ranging from $2^{0}$ to $2^{10}$. Two starting solutions (stock solutions) were employed, the concentrations being $0.1 \mathrm{~g} / \mathrm{L}$ and $1 \mathrm{~g} / \mathrm{L}$. These values were selected based on the IL concentration determined (see Table 2) and with the aim of using the same initial concentration in order for the results to be easily comparable. Therefore, the concentrations of the stock solutions were the following: $0.1 \mathrm{~g} / \mathrm{L}$ for $\left[\mathrm{P}_{6,6,6,14}\right][\mathrm{TFSI}],\left[\mathrm{P}_{6,6,6,14}\right][\mathrm{DCA}],\left[\mathrm{C}_{12} \mathrm{C}_{1} \mathrm{IM}\right][\mathrm{TFSI}],\left[\mathrm{C}_{10} \mathrm{C}_{1} \mathrm{C}_{10} \mathrm{IM}\right][\mathrm{TFSI}],\left[\mathrm{N}_{8881}\right][\mathrm{TFSI}]$, ZDDP1 and ZDDP2 and $1 \mathrm{~g} / \mathrm{L}$ for $\left[\mathrm{P}_{6,6,6,14}\right]\left[\left(\mathrm{iC}_{8}\right)_{2} \mathrm{PO}_{2}\right],\left[\mathrm{P}_{6,6,6,14}\right][\mathrm{Cl}],\left[\mathrm{P}_{6,6,6,14}\right][\mathrm{BEHP}],\left[\mathrm{N}_{4441}\right][\mathrm{TFSI}],\left[\mathrm{P}_{4,4,4,14}\right][\mathrm{DBS}],\left[\mathrm{N}_{4441}\right][\mathrm{DCA}]$ and $\left[\mathrm{P}_{4442}\right][\mathrm{DEP}] \mathrm{ILs}$. The temperature was hold at $15^{\circ} \mathrm{C}$ using a water bath and salinity was fixed at $2 \%$ after a $\mathrm{pH}$ adjustment from 6.5 to 7.5 was carried out. The equipment employed was a Luminometer BioFix ${ }^{\circledR}$ Lumi-10. Results were expressed in accordance with the ISO 11348-3 [81]. The inhibition percentage (IL) was determined comparing the fall in light emission with a toxic-free $2 \% \mathrm{NaCl}$ solution (control sample) after 15 min of contact with the bacteria. Since bacterial luminescence (light emission) is proportional to cellular respiration in a direct way, a decrease in light emission indicates reduced respiration due to the presence of substances that are toxic to the bacteria. The concentration of additive, which reduces the luminescence of bacteria by $50 \%$ after 15 min of exposure $\left(\mathrm{EC}_{50}\right)$, was determined [83]. In addition, the toxic units (TU) were calculated after a contact time of $15 \mathrm{~min}$. This unit is the reciprocal of the IL concentration that provoke the death of $50 \%$ of the bacteria after the exposure period. It is determined dividing the concentration of the IL, which is $100 \%$, by lethal end-point $\left(\mathrm{EC}_{50}\right)$, according to eq. (2) [84]. These units make easier the understanding of toxicity measurements, since an increase in the TU value implies an increase in the toxicity.

$$
T U=\frac{1}{E C_{50}} \times 100
$$

TU is a unitless parameter, which indicates relative toxicity and classifies the substances into four categories: i) non-toxic: $\mathrm{TU}$ values lower than 1, ii) toxic: $\mathrm{TU}$ values from 1 to 10 , iii) very toxic: $\mathrm{TU}$ values between 10 and 100 , and iv) extremely toxic: TU values higher than $100[83,85]$. All analytical measurements were carried out at least three times.

\subsubsection{Staining procedure and fluorescence measurements}

This procedure was carried out to assess the viability of Vibrio fischeri after performing the toxicity tests. The solution (IL and bacteria) was centrifuged at $15000 \mathrm{~g}$ for $5 \mathrm{~min}$ in order to separate the bacteria from the IL. Before staining, it was necessary to wash the bacteria twice with sterile-filtered PBS (phosphate-buffered 
saline; $\mathrm{pH}$ 7.4), and sonicate them for 2 seconds to avoid cellular aggregation. Afterwards, the supernatant was removed and the bacteria were resuspended in PBS. Next, $250 \mu \mathrm{L}$ of this suspension were added to two staining solutions prepared beforehand. Two fluorescents dyes, propidium iodide (PI, Invitrogen) and carboxyfluorescein diacetate (cFDA, Invitrogen), were employed in a dual-staining procedure. The working solutions of PI and cFDA were prepared according to Alonso et al. [86]. Firstly, the sample was stained with PI and incubated for $30 \mathrm{~min}$ in darkness at $20^{\circ} \mathrm{C}$. Then, the PI-stained sample was incubated with cFDA for 15 min in darkness at $20^{\circ} \mathrm{C}$. Thus, the metabolic activity and membrane integrity of Vibrio fischeri, i.e. its physiological status, was evaluated using cFDA and PI, respectively.

Fluorescence measurements were carried out using a Leica DMR-XA fluorescence microscope equipped with HBO100 Mercury Arc Lamp. Green fluorescence from the suspensions, which corresponds to cFDA-stained bacteria, was registered on the L5 blue filter, whereas the PI-stained ones were collected with N2.1 green filter. Each analysis was conducted in duplicate. Images acquisition was performed using the software QFluoro from Leica Microsystems.

\subsubsection{E. coli tests}

A colorimetric assay: Toxi-ChromoTest (epbi - version 3.6) was employed in order to obtain an additional value of bacterial toxicity of the samples. According to Chow et al. [87], this assay is based on the capacity of different substances to inhibit the $\beta$-galactosidase enzyme in a greatly sensitive Escherichia coli strain. These assays were carried out with serial two-fold aqueous dilutions ranging from $2^{0}$ to $2^{10}$ (triplicate samples). The concentrations of the starting solutions (stock solutions) were the same as those used in the Vibrio fischeri bioassays $(0.1 \mathrm{~g} / \mathrm{L}$ or $1 \mathrm{~g} / \mathrm{L})$. The exposure of the bacteria to the additive solutions was $90 \mathrm{~min}$. After this incubation period, a chromogenic substrate (blue chromogen) was added. If the sample is found to be toxic, no colour will be visible. Nevertheless, a distinctive blue colour quickly appears with non-toxic samples. To quantify the colour observed, the optical density was tested with a Cary Uv/Vis spectrophotometer at $615 \mathrm{~nm}$ (for blue colour). The toxicity (degree of inhibition) was calculated by comparison with the optical density of the control sample free of toxicants. Mercury chloride $(4 \mathrm{mg} / \mathrm{L})$ was used as a standard toxic substance in order to check the viability of the $E$. coli strain. Both the values of $\mathrm{EC}_{50}$, that is to say the concentration that inhibits enzymatic activity by $50 \%$, and TU units were calculated after 90 min of incubation. 


\section{Results and discussion}

\subsection{Ecotoxicity analysis}

\subsubsection{Vibrio fischeri tests: calculation}

Table 3 shows the values of bacterial toxicity for the marine bacteria after $15 \mathrm{~min}$ of exposure in terms of $\mathrm{EC}_{50}(\mathrm{mg} / \mathrm{L})$. Toxicity values followed this sequence: $\left[\mathrm{P}_{6,6,6,14}\right][\mathrm{TFSI}]>\left[\mathrm{P}_{6,6,6,14}\right][\mathrm{DCA}]>$ $\left[\mathrm{C}_{10} \mathrm{C}_{1} \mathrm{C}_{10} \mathrm{IM}\right][\mathrm{TFSI}]>\left[\mathrm{C}_{12} \mathrm{C}_{1} \mathrm{IM}\right][\mathrm{TFSI}]>\left[\mathrm{P}_{6,6,6,14}\right][\mathrm{Cl}]>\left[\mathrm{N}_{8881}\right][\mathrm{TFSI}]>\left[\mathrm{P}_{4,4,4,14}\right][\mathrm{DBS}]>\left[\mathrm{N}_{4441}\right][\mathrm{TFSI}]$ $>\left[\mathrm{N}_{4441}\right][\mathrm{DCA}]>\left[\mathrm{P}_{6,6,6,14}\right]\left[\left(\mathrm{iC}_{8}\right)_{2} \mathrm{PO}_{2}\right]>\left[\mathrm{P}_{6,6,6,14}\right][\mathrm{BEHP}]>\left[\mathrm{P}_{4442}\right][\mathrm{DEP}]$.

It is worth noting that $\mathrm{EC}_{50}$ values of the samples studied are mainly controlled by the cationic part, especially if it contains long carbon chains [88-92]. Although the influence of the anionic part on toxicity is less predictable [2,93], from these data it can be concluded that the toxicity of these ILs also depends considerably on the anion. In this sense, the $\mathrm{EC}_{50}$ of $\left[\mathrm{P}_{6,6,6,14}\right]\left[\left(\mathrm{iC}_{8}\right)_{2} \mathrm{PO}_{2}\right]$ was approximately twenty two times higher than that of $\left[\mathrm{P}_{6,6,6,14}\right][\mathrm{TFSI}] \mathrm{IL}(1.3 \mathrm{mg} / \mathrm{L})$. On the other hand, the "side chain effect" found by various authors in imidazolium ILs was also observed in the ILs here analysed. This effect refers to the observation that longer alkyl chain length causes a rise in toxicity $[11,94]$. This is the reason why the $\mathrm{EC}_{50}$ value for $\left[\mathrm{C}_{10} \mathrm{C}_{1} \mathrm{C}_{10} \mathrm{IM}\right][\mathrm{TFSI}]$ was slightly higher than that for $\left[\mathrm{C}_{12} \mathrm{C}_{1} \mathrm{IM}\right][\mathrm{TFSI}]$. Therefore, the nature of both ions had a significant influence on bacterial toxicity of ionic liquids. It should be reported that ZDDP1 and ZDDP2 were found to be the most toxic samples. This can be mainly explained by the presence of zinc in their composition, which is highly toxic to Vibrio fischeri [95]. Table 3 shows the toxic units (TU), which can also be used as a measurement of the toxic action of the ILs and ZDDPs.

According to GHS (Globally Harmonized System of Classification and Labelling of Chemicals) [96, 97], the $\left[\mathrm{P}_{6,6,6,14}\right][\mathrm{TFSI}],\left[\mathrm{P}_{6,6,6,14}\right][\mathrm{DCA}],\left[\mathrm{P}_{6,6,6,14}\right][\mathrm{Cl}],\left[\mathrm{C}_{12} \mathrm{C}_{1} \mathrm{IM}\right][\mathrm{TFSI}],\left[\mathrm{C}_{10} \mathrm{C}_{1} \mathrm{C}_{10} \mathrm{IM}\right][\mathrm{TFSI}]$ and ZDDP1 can be placed in the category of "toxic to the aquatic environment": namely, category Acute $2\left(\mathrm{EC}_{50}\right.$ between 1 and $10 \mathrm{mg} / \mathrm{L})$. In addition, ZDDP2 can be included in the category Acute $1\left(\mathrm{EC}_{50}<1 \mathrm{mg} / \mathrm{L}\right)$. The other analyzed ILs can be classified as harmful (category Acute 3), with $\mathrm{EC}_{50}$ values ranging from $10-100 \mathrm{mg} / \mathrm{L}$. 
Table 3. $\mathrm{EC}_{50}$ values for the Vibrio fischeri of ILs and ZDDPs (exposure: $15 \mathrm{~min}$ ).

\begin{tabular}{lcc}
\hline Sample & $\mathbf{E C}_{\mathbf{5 0}}(\mathbf{m g} / \mathbf{L})^{\mathbf{a}}$ & $\mathbf{T U}^{\mathbf{b}}$ \\
\hline$\left[\mathrm{P}_{6,6,6,14}\right]\left[\left(\mathrm{iC}_{8}\right)_{2} \mathrm{PO}_{2}\right]$ & $28.3 \pm 0.7$ & 3.53 \\
{$\left[\mathrm{P}_{6,6,6,14}\right][\mathrm{BEHP}]$} & $30.2 \pm 0.9$ & 3.31 \\
{$\left[\mathrm{P}_{6,6,6,14}\right][\mathrm{TFSI}]$} & $1.3 \pm 0.6$ & 76.92 \\
{$\left[\mathrm{P}_{6,6,6,14}\right][\mathrm{DCA}]$} & $4.4 \pm 0.5$ & 22.73 \\
{$\left[\mathrm{P}_{6,6,6,14}\right][\mathrm{Cl}]$} & $7.8 \pm 0.3$ & 12.82 \\
{$\left[\mathrm{P}_{4,4,4,14}\right][\mathrm{DBS}]$} & $14.4 \pm 0.5$ & 6.94 \\
{$\left[\mathrm{P}_{4442}\right][\mathrm{DEP}]$} & $55.2 \pm 0.7$ & 1.81 \\
{$\left[\mathrm{C}_{12} \mathrm{C}_{1} \mathrm{IM}\right][\mathrm{TFSI}]$} & $7.3 \pm 0.6$ & 13.70 \\
{$\left[\mathrm{C}_{10} \mathrm{C}_{1} \mathrm{C}_{10} \mathrm{IM}\right][\mathrm{TFSI}]$} & $6.8 \pm 0.9$ & 14.71 \\
{$\left[\mathrm{~N}_{8881}\right][\mathrm{TFSI}]$} & $12.9 \pm 0.3$ & 7.75 \\
{$\left[\mathrm{~N}_{4441}\right][\mathrm{TFSI}]$} & $17.6 \pm 0.4$ & 5.68 \\
{$\left[\mathrm{~N}_{4441}\right][\mathrm{DCA}]$} & $21.1 \pm 0.6$ & 4.74 \\
ZDDP1 & $1.0 \pm 0.2$ & 100.00 \\
ZDDP2 & $0.9 \pm 0.1$ & 111.11 \\
\hline
\end{tabular}

${ }^{a} \mathbf{E C}_{50}$ classification for aquatic life: non-toxic: $\mathrm{EC}_{50}>100 \mathrm{mg} / \mathrm{L}$; harmful (acute 3): $\mathrm{EC}_{50}$ : $10-100 \mathrm{mg} / \mathrm{L}$; toxic (acute 2): $\mathrm{EC}_{50}: 1-10 \mathrm{mg} / \mathrm{L}$; and very toxic (acute 1 ): $\mathrm{EC}_{50}<1 \mathrm{mg} / \mathrm{L}$.

b TU classification: non-toxic: TU $<1$; toxic: TU: $1-10$; very toxic: TU: $10-100$ and extremely toxic: $\mathrm{TU}>100$

Figure 2 shows the green and red fluorescence merged images of Vibrio fischeri after being in contact with the control sample $\left(2 \% \mathrm{NaCl}\right.$ solution), $\left[\mathrm{P}_{4442}\right][\mathrm{DEP}]$ and $\left[\mathrm{P}_{6,6,6,14}\right][\mathrm{TFSI}]$ (at a concentration of $0.1 \mathrm{~g} / \mathrm{L}$ ) for 15 min. The use of a dual staining, cFDA-PI, enabled to identify three different subpopulations of Vibrio fischeri: active, damaged and dead ones. In this sense, PI is a red-fluorescent nucleic acid dye, which stains damaged and dead cells, and cFDA is a fluorogenic ester that can only diffuse into living cells. It is hydrolised by an intracellular enzyme (estearase) to yield fluorescein, a green fluorescent product $[86,98]$. Therefore, the green colour indicates active/living cells, the red one represents dead cells and the yellow one depicts damaged cells. As expected, in the control sample, only active/healthy cells can be distinguished due to the absence of toxicity (Fig. 2a). In this case, the bacteria were not stained by PI since the membrane remained intact. Nevertheless, all of the bacteria displayed in Fig $2 \mathrm{~b}$ and $\mathrm{c}$ are dead. This can be attributed to the fact that $\left[\mathrm{P}_{6,6,6,14}\right][\mathrm{TFSI}]$ and ZDDP2 caused the loss of metabolic activity and adversely affected the integrity of the cell membrane, thus allowing PI to diffuse into the membrane. Therefore, these images allowed us to validate the toxicity results, in which $\left[\mathrm{P}_{6,6,6,14}\right][\mathrm{TFSI}]$ and ZDDP2 were revealed as the most toxic substances. In the case of $\left[\mathrm{P}_{4442}\right][\mathrm{DEP}]$, all the subpopulations (active, damaged and dead cells) were identified (Figure 
2d). This can be explained considering that this IL has a lower impact on both the metabolic activity and the integrity of the cell membrane. The information disclosed by this image is in agreement with the toxicity tests, which showed that $\left[\mathrm{P}_{4442}\right][\mathrm{DEP}]$ was the least toxic among the studied ILs.
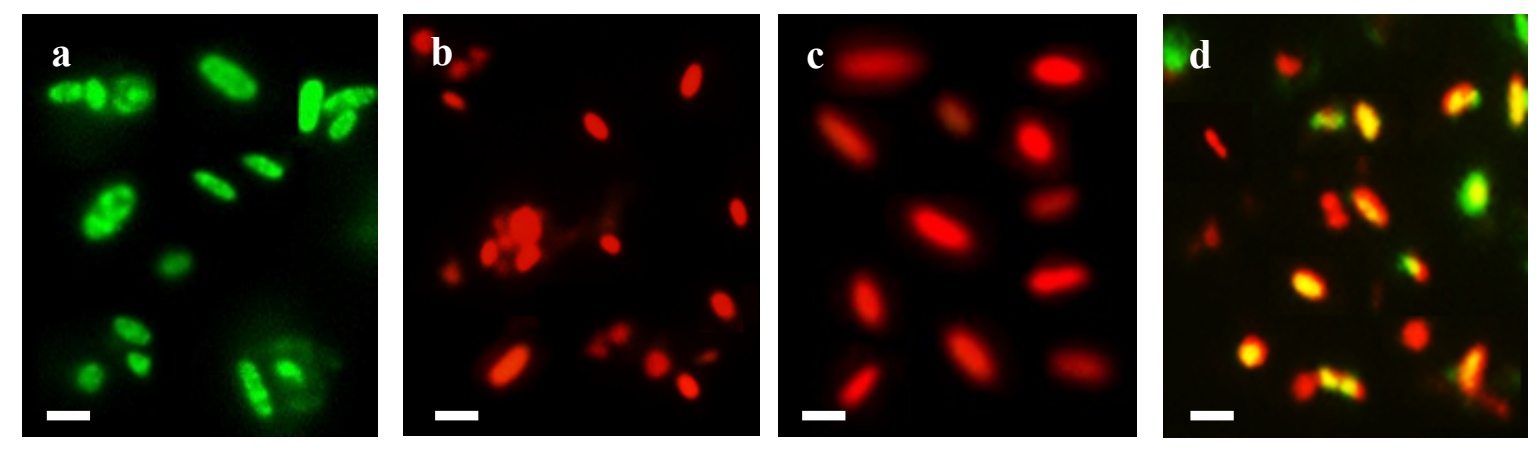

Fig. 2. Overlay of the green and red fluorescence images of Vibrio fischeri cells after a contact time of 15 min. a) $2 \% \mathrm{NaCl}$ solution (control sample), b) $0.1 \mathrm{~g} / \mathrm{L}$ of [ $\left.\mathrm{P}_{6,6,6,14}\right]$ [TFSI] , c) $0.1 \mathrm{~g} / \mathrm{L}$ of [ZDDP2] and d) 0.1 $\mathrm{g} / \mathrm{L}\left[\mathrm{P}_{4442}\right][\mathrm{DEP}]$. Scale bars: $2.5 \mu \mathrm{m}$.

Based on TU data, ZDDP1 and ZDDP2 fell into the category of very toxic (TU between 1 and 100) and extremely toxic $(\mathrm{TU}>100)$, respectively, whereas $\left[\mathrm{P}_{6,6,6,14}\right]\left[\left(\mathrm{iC}_{8}\right)_{2} \mathrm{PO}_{2}\right],\left[\mathrm{P}_{6,6,6,14}\right][\mathrm{BEHP}],\left[\mathrm{P}_{4,4,4,14}\right][\mathrm{DBS}]$, $\left[\mathrm{P}_{4442}\right][\mathrm{DEP}],\left[\mathrm{N}_{8881}\right][\mathrm{TFSI}],\left[\mathrm{N}_{4441}\right][\mathrm{TFSI}]$ and $\left[\mathrm{N}_{4441}\right][\mathrm{DCA}]$ can be classified as toxic. Therefore, most of the studied ILs had TU values that were lower or much lower than the traditional oil additive ZDDP (see ZDDP1 and ZDDP2 values). This fact, combined with the excellent solubility and tribological performance shown by $\left[\mathrm{P}_{6,6,6,14}\right]\left[\left(\mathrm{iC}_{8}\right)_{2} \mathrm{PO}_{2}\right]$ and $\left[\mathrm{P}_{6,6,6,14}\right][\mathrm{BEHP}]$ in several lubrication studies $[25,42,45,48,54]$, suggests the possibility of using them as an alternative to this harmful traditional additive. Fig 3. showed the friction results from 60 minutes reciprocating ball on plate tests conducted at a load of $60 \mathrm{~N}$ (1.91 GPa of maximum contact pressure), a frequency of $15 \mathrm{~Hz}$, a stroke length of $4 \mathrm{~mm}$ and $4 \mathrm{ml}$ of the corresponding lubricant sample. Finally, $\left[\mathrm{P}_{6,6,6,14}\right]\left[\left(\mathrm{iC}_{8}\right)_{2} \mathrm{PO}_{2}\right],\left[\mathrm{P}_{6,6,6,14}\right][\mathrm{BEHP}]$ and $\mathrm{ZDDP}$ were employed as additive in a mineral oil (Yubase 4) [48]. 


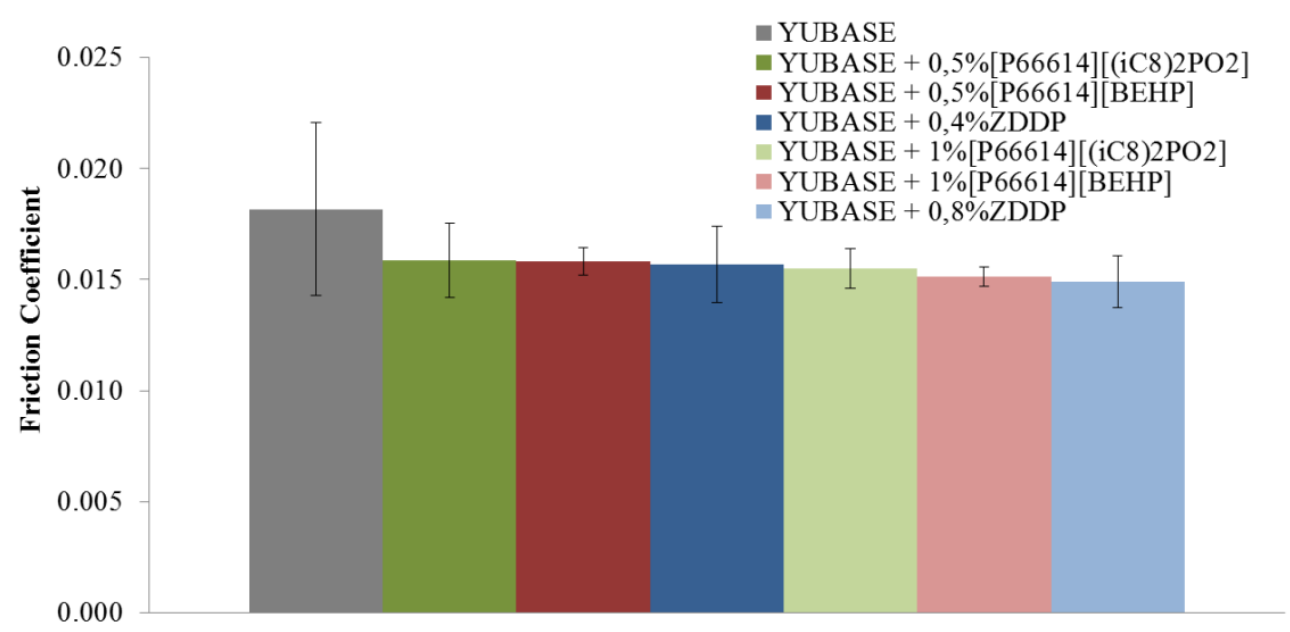

Fig. 3. Mean friction coefficient and deviation of tribological tests made with $\left[\mathrm{P}_{6,6,6,14}\right]\left[\left(\mathrm{iC}_{8}\right)_{2} \mathrm{PO}_{2}\right]$, $\left[\mathrm{P}_{6,6,6,14}\right][\mathrm{BEHP}]$ and ZDDP as additive in Yubase 4 [48].

Regarding the results shown in Fig. 3, the use of similar concentration of phosphorus in the ionic liquids and ZDDP leads to similar friction values, supporting the possibility that these ILs can partially or totally replace ZDDP. Analyzing the antiwear behavior (Table 4), all the mixtures exhibited clear wear reduction properties compared to the neat base oil.

Table 4. Wear results after 60-minutes tests [48].

\begin{tabular}{|c|c|c|}
\hline \multirow[b]{2}{*}{ Lubricants } & \multicolumn{2}{|c|}{ 60-minutes tests } \\
\hline & $\begin{array}{c}\text { Wear volume } \\
\left(\mu \mathrm{m}^{3}\right) \times 10^{6}\end{array}$ & Std. Dev. \\
\hline YUBASE & 19.20 & 2.451 \\
\hline YUBASE $+0.5 \%\left[\mathrm{P}_{6,6,6,14}\right]\left[\left(\mathrm{iC}_{8}\right)_{2} \mathrm{PO}_{2}\right]$ & 6.018 & 2.689 \\
\hline YUBASE + 0.5\% $\left[\mathrm{P}_{6,6,6,14}\right][\mathrm{BEHP}]$ & 13.58 & 1.013 \\
\hline YUBASE + 0.4\% ZDDP & 6.998 & 1.215 \\
\hline YUBASE $+1 \%\left[\mathrm{P}_{6,6,6,14}\right]\left[\left(\mathrm{iC}_{8}\right)_{2} \mathrm{PO}_{2}\right]$ & 4.736 & 1.220 \\
\hline YUBASE + $1 \%\left[\mathrm{P}_{6,6,6,14}\right][\mathrm{BEHP}]$ & 8.013 & 0.607 \\
\hline YUBASE + 0.8\% ZDDP & 5.339 & 0.391 \\
\hline
\end{tabular}

In addition, $\left[\mathrm{P}_{6,6,6,14}\right]\left[\left(\mathrm{iC}_{8}\right)_{2} \mathrm{PO}_{2}\right]$ ionic liquid showed an excellent antiwear behavior, even outperforming the mixtures containing ZDDP. Besides, increasing the amount of ionic liquid and ZDDP in the mixtures improved as expected the antiwear behavior of all samples. 


\subsubsection{Vibrio fischeri tests: estimation}

A basic model was developed for a preliminary estimate of the effect of both ions on bacterial toxicity (in terms of $\mathrm{EC}_{50}$ ), determining which ones are the most toxic. In order to draw significant conclusions from the model, it is necessary to combine different cation species with several anions and vice versa, obtaining ILs sharing either the cationic or the anionic part. This model is based on the Quantitative Structure-Activity Relationship (QSAR) method [91, 99], which evaluates the effect of structural properties of the ILs on the toxicity against bacteria, mainly Vibrio Fischeri. However, our model is different and simpler than the QSAR one, since it is considered that the value of $\mathrm{EC}_{50}$ is due to both the anion and cation contributions without analyzing the interactions between them. Thus, a parameter was assigned to each ion present in the ionic liquid, the parameters being: $1 / \mathrm{C}_{\mathrm{i}}$ for the cations, with "i" ranging from 1 to 5 for $\left[\mathrm{P}_{6,6,6,14}\right]^{+},\left[\mathrm{C}_{12} \mathrm{C}_{1} \mathrm{IM}\right]^{+}$, $\left[\mathrm{C}_{10} \mathrm{C}_{1} \mathrm{C}_{10} \mathrm{IM}\right]^{+},\left[\mathrm{N}_{8881}\right]^{+}$and $\left[\mathrm{N}_{4441}\right]^{+}$, respectively and $1 / \mathrm{A}_{\mathrm{j}}$ for the anions with " $\mathrm{j}$ " varying between 1 and 5 for $\left.\left[\left(\mathrm{iC}_{8}\right)_{2} \mathrm{PO}_{2}\right]^{-},{ }^{-} \mathrm{BEHP}\right]^{-},[\mathrm{TFSI}]^{-},[\mathrm{DCA}]^{-}$and [Cl]-, respectively.

The values of the parameters $1 / \mathrm{C}_{\mathrm{i}}$ and $1 / \mathrm{A}_{\mathrm{j}}$ were obtained from a linear fitting of the $\mathrm{EC}_{50}$ values determined using the following equation (Eq. 3) for the ionic liquid formed by cation " $\mathrm{C}_{\mathrm{i}}$ " and anion " $\mathrm{A}_{\mathrm{j}}$ ":

$$
\mathrm{EC}_{50}\left(\mathrm{C}_{\mathrm{i}} \mathrm{A}_{\mathrm{j}}\right)=1 / \mathrm{C}_{\mathrm{i}}+1 / \mathrm{A}_{\mathrm{j}}
$$

In order to obtain unique solutions for the model parameters, each cation and anion must be present in at least two of the ILs studied. Otherwise, multiple solutions would exist for the parameters of the ions, which appear only in one of the ILs. This is the reason why the cations $\left[\mathrm{P}_{4,4,4,14}\right]^{+}$and $\left[\mathrm{P}_{4442}\right]^{+}$and the anions $[\mathrm{DBS}]^{-}$and $[D E P]^{-}$could not be included in the model. The model fitting was performed with Scientist 3.0 software (MicroMath, Inc.), the values of $\mathrm{R}^{2}$ being higher than 0.99 in all cases. Table 4 summarizes the information related to $\mathrm{C}_{\mathrm{i}}$ and $\mathrm{A}_{\mathrm{j}}$ parameters.

Table 5. Values of the model parameters $\mathrm{C}_{\mathrm{i}}$ and $\mathrm{A}_{\mathrm{j}}$ obtained from Vibrio fischeri data.

\begin{tabular}{lclc}
\hline Cation & $\mathbf{C}_{\mathbf{i}}(\mathbf{L} / \mathbf{m g})$ & Anion & $\mathbf{A}_{\mathbf{j}}(\mathbf{L} / \mathbf{m g})$ \\
\hline$\left[\mathrm{P}_{6,6,6,14}\right]^{+}$ & $9.94 \cdot 10^{-1}$ & {$[\mathrm{TFSI}]^{-}$} & 3.54 \\
{$\left[\mathrm{C}_{10} \mathrm{C}_{1} \mathrm{C}_{10} \mathrm{IM}\right]^{+}$} & $1.53 \cdot 10^{-1}$ & {$[\mathrm{DCA}]^{-}$} & $2.91 \cdot 10^{-1}$ \\
{$\left[\mathrm{C}_{12} \mathrm{C}_{1} \mathrm{IM}\right]^{+}$} & $1.43 \cdot 10^{-1}$ & {$[\mathrm{Cl}]^{-}$} & $1.47 \cdot 10^{-1}$ \\
{$\left[\mathrm{~N}_{8881}\right]^{+}$} & $7.93 \cdot 10^{-2}$ & {$\left[\left(\mathrm{iC}_{8}\right)_{2} \mathrm{PO}_{2}\right]^{-}$} & $3.66 \cdot 10^{-2}$ \\
{$\left[\mathrm{~N}_{4441}\right]^{+}$} & $5.72 \cdot 10^{-2}$ & {$[\mathrm{BEHP}]^{-}$} & $3.43 \cdot 10^{-2}$ \\
\hline
\end{tabular}

It should be borne in mind that the toxicity of the corresponding cation or anion is directly proportional to the $\mathrm{C}_{\mathrm{i}}$ and $\mathrm{A}_{\mathrm{j}}$ numerical values. The toxicity of the cationic part decreased as follows: $\left[\mathrm{P}_{6,6,6,14}\right]^{+}>\left[\mathrm{C}_{10} \mathrm{C}_{1} \mathrm{C}_{10} \mathrm{IM}\right]^{+}$ 
$>\left[\mathrm{C}_{12} \mathrm{C}_{1} \mathrm{IM}\right]^{+}>\left[\mathrm{N}_{1881}\right]^{+}>\left[\mathrm{N}_{4441}\right]^{+}$. The $\left[\mathrm{P}_{6,6,6,14}\right]^{+}$cation had the highest toxicity, whereas $\left[\mathrm{N}_{4441}\right]^{+}$exhibited the lowest. This agrees with the findings of other authors, who reported that aromatic cations (such as imidazolium) are more toxic for Vibrio fischeri than those bearing ammonium ones [2, 80 87]. Besides, Ventura et al. [11] pointed out that the toxicity to Vibrio fischeri of the phosphonium family is greater than that of the imidazolium family. Regarding the toxicity of the anion, the trend was as follows: [TFSI] $>$ $[\mathrm{DCA}]^{-}>[\mathrm{Cl}]^{-}>\left[\left(\mathrm{iC}_{8}\right)_{2} \mathrm{PO}_{2}\right]^{-}>[\mathrm{BEHP}]^{-}$.

These results are in accordance with those found in the literature, which reported that the substitution of [Cl]by [TFSI]- increased toxicity significantly (up to one hundred times) against Vibrio fischeri [88]. Moreover, the $[\mathrm{DCA}]^{-}$anion was also considered acutely toxic for these marine bacteria [2].

\subsubsection{Toxi-ChromoTest tests: calculation}

This bacterial colorimetric test is an ecotoxicological assay, which has been verified by the Environmental Protection Agency (USA). This test is becoming a standard tool because of its cost, time effective and sensitivity to low concentrations of toxic substances.

The results related to the toxicity $\left(\mathrm{EC}_{50}\right)$ of the modified $E$. coli bacteria after $90 \mathrm{~min}$ of incubation are shown in Table 5 . The degree of enzyme inhibition caused by the IL solutions followed this trend: $\left[\mathrm{P}_{6,6,6,14}\right][\mathrm{TFSI}]>$ $\left[\mathrm{C}_{10} \mathrm{C}_{1} \mathrm{C}_{10} \mathrm{IM}\right][\mathrm{TFSI}]=\left[\mathrm{C}_{12} \mathrm{C}_{1} \mathrm{IM}\right][\mathrm{TFSI}]>\left[\mathrm{P}_{6,6,6,14}\right][\mathrm{DCA}]>\left[\mathrm{P}_{6,6,6,14}\right][\mathrm{Cl}]>\left[\mathrm{N}_{8881}\right][\mathrm{TFSI}]>\left[\mathrm{N}_{4441}\right][\mathrm{TFSI}]>$ $\left[\mathrm{P}_{4,4,4,14}\right][\mathrm{DBS}]>\left[\mathrm{N}_{4441}\right][\mathrm{DCA}]>\left[\mathrm{P}_{6,6,6,14}\right][\mathrm{BEHP}]>\left[\mathrm{P}_{6,6,6,14}\right]\left[\left(\mathrm{iC}_{8}\right)_{2} \mathrm{PO}_{2}\right]>\left[\mathrm{P}_{4442}\right][\mathrm{DEP}]$. As can be seen from the $\mathrm{EC}_{50}$ values of $\left[\mathrm{P}_{66614}\right]$ cation-based ILs, the nature of the anion affected their toxicity largely. Thus, the $\mathrm{EC}_{50}$ of $\left[\mathrm{P}_{6,6,6,14}\right][\mathrm{TFSI}]$ and $\left[\mathrm{P}_{6,6,6,14}\right][\mathrm{DCA}]$ ILs were around 4 and 2.5 times lower than that of $\left[\mathrm{P}_{6,6,6,14}\right][\mathrm{Cl}]$ IL, respectively. Similar behaviour was found by other authors, who reported that the replacement of halides $\left(\mathrm{Cl}^{-}\right.$or $\left.\mathrm{Br}^{-}\right)$by other anions, such as [TFSI]- or [DCA $]^{-}$, resulted in a reduction in bacterial activity [100].

Considering imidazolium ILs, the values of $\mathrm{EC}_{50}$ were identical for $\left[\mathrm{C}_{10} \mathrm{C}_{1} \mathrm{C}_{10} \mathrm{IM}\right][\mathrm{TFSI}]$ and $\left[\mathrm{C}_{12} \mathrm{C}_{1} \mathrm{IM}\right][\mathrm{TFSI}]$. This indicated the existence of a "cutoff" effect, in which, once a certain length is reached, a further increase in the chain has no further impact on toxicity $[2,83,88]$. This effect was reported in research studies using highly lipophilic compounds [89] and the imidazolium-based ILs analysed here can be included within this group, since they are poorly soluble in an aqueous medium (Table 2). In this case, ZDDP1 and ZDDP2 were also found to be the most toxic samples. Again, this may be principally due to the 
presence in their composition of zinc, which is very toxic for E. coli, even at low concentrations [101]. Toxic units (TU) were summarized in Table 6.

Table 6. $\mathrm{EC}_{50}$ and TU values for E. coli after 90 min of incubation at $37^{\circ} \mathrm{C}$.

\begin{tabular}{lcc}
\hline Sample & $\mathbf{E C}_{\mathbf{5 0}} \mathbf{( \mathbf { m g } / \mathbf { L } ) ^ { \mathbf { a } }}$ & $\mathbf{T U}^{\mathbf{b}}$ \\
\hline$\left[\mathrm{P}_{6,6,6,14}\right]\left[\left(\mathrm{iC}_{8}\right)_{2} \mathrm{PO}_{2}\right]$ & $33.1 \pm 0.5$ & 3.02 \\
{$\left[\mathrm{P}_{6,6,6,14}\right][\mathrm{BEHP}]$} & $26.0 \pm 0.3$ & 3.85 \\
{$\left[\mathrm{P}_{6,6,6,14][\mathrm{TFSI}]}\right.$} & $1.6 \pm 0.2$ & 62.50 \\
{$\left[\mathrm{P}_{6,6,6,14}\right][\mathrm{DCA}]$} & $4.0 \pm 0.3$ & 25.00 \\
{$\left[\mathrm{P}_{6,6,6,14}\right][\mathrm{Cl}]$} & $6.2 \pm 0.5$ & 16.13 \\
{$\left[\mathrm{P}_{4,4,4,14}\right][\mathrm{DBS}]$} & $11.6 \pm 0.4$ & 8.62 \\
{$\left[\mathrm{P}_{4442}\right][\mathrm{DEP}]$} & $39.1 \pm 0.6$ & 2.56 \\
{$\left[\mathrm{C}_{12} \mathrm{C}_{1} \mathrm{IM}\right][\mathrm{TFSI}]$} & $3.1 \pm 0.7$ & 32.25 \\
{$\left[\mathrm{C}_{10} \mathrm{C}_{1} \mathrm{C}_{10} \mathrm{IM}\right][\mathrm{TFSI}]$} & $3.1 \pm 0.5$ & 32.11 \\
{$\left[\mathrm{~N}_{8881}\right][\mathrm{TFSI}]$} & $6.5 \pm 0.3$ & 15.38 \\
{$\left[\mathrm{~N}_{4441}\right][\mathrm{TFSI}]$} & $10.4 \pm 0.4$ & 9.62 \\
{$\left[\mathrm{~N}_{4441}\right][\mathrm{DCA}]$} & $12.7 \pm 0.8$ & 7.87 \\
$\mathrm{ZDDP} 1$ & $0.9 \pm 0.2$ & 11.11 \\
$\mathrm{ZDDP} 2$ & $0.8 \pm 0.2$ & 125.00 \\
\hline
\end{tabular}

${ }^{a} \mathbf{E C}_{50}$ classification for aquatic life: non-toxic: $\mathrm{EC}_{50}>100 \mathrm{mg} / \mathrm{L}$; harmful (acute 3): $\mathrm{EC}_{50}$ : $10-100 \mathrm{mg} / \mathrm{L}$; toxic (acute 2): $\mathrm{EC}_{50}: 1-10 \mathrm{mg} / \mathrm{L}$; and very toxic (acute 1 ): $\mathrm{EC}_{50}<1 \mathrm{mg} / \mathrm{L}$.

b TU classification: non-toxic: TU $<1$; toxic: TU: $1-10$; very toxic: TU: $10-100$ and extremely toxic: $\mathrm{TU}>100$

Considering the GHS classification, the $\left[\mathrm{P}_{6,6,6,14}\right][\mathrm{TFSI}],\left[\mathrm{P}_{6,6,6,14}\right][\mathrm{DCA}],\left[\mathrm{P}_{6,6,6,14}\right][\mathrm{Cl}],\left[\mathrm{C}_{12} \mathrm{C}_{1} \mathrm{IM}\right][\mathrm{TFSI}]$, $\left[\mathrm{C}_{10} \mathrm{C}_{1} \mathrm{C}_{10} \mathrm{IM}\right][\mathrm{TFSI}]$ and $\left[\mathrm{N}_{8881}\right][\mathrm{TFSI}]$ ILs are toxic for the aquatic environment $\left(\mathrm{EC}_{50}\right.$ values between 1-10 $\mathrm{mg} / \mathrm{L}$ ), whereas ZDDP1 and ZDDP2, with $\mathrm{EC}_{50}$ values $<1 \mathrm{mg} / \mathrm{L}$, can be considered as very toxic. The other ILs studied can be included in the category of harmful $\left(\mathrm{EC}_{50}\right.$ varied from 10 to $\left.100 \mathrm{mg} / \mathrm{L}\right)$. Taking into account TU data, ZDDP1 and ZDDP2, can be considered as extremely toxic compounds, whereas $\left[\mathrm{P}_{6,6,6,14}\right]\left[\left(\mathrm{iC}_{8}\right)_{2} \mathrm{PO}_{2}\right],\left[\mathrm{P}_{6,6,6,14}\right][\mathrm{BEHP}],\left[\mathrm{P}_{4,4,4,14}\right][\mathrm{DBS}],\left[\mathrm{P}_{4442}\right][\mathrm{DEP}],\left[\mathrm{N}_{4441}\right][\mathrm{TFSI}]$ and $\left[\mathrm{N}_{4441}\right][\mathrm{DCA}]$ can be categorised as toxic. On viewing these results, the ILs proved to be again either less or much less toxic to $E$. coli than the traditional lubricant additive ZDDP. 


\subsubsection{Toxi-ChromoTest tests: estimation}

As with the Vibrio fischeri, a basic model was established to allow preliminary evaluation of the influence of both ions on ionic liquid toxicity. The data related to the values of model parameters $C_{i}$ and $A_{j}$ are set out in Table 7.

Table 7. Model parameters $\mathrm{C}_{\mathrm{i}}$ and $\mathrm{A}_{\mathrm{j} .}$ obtained from E. coli data.

\begin{tabular}{lclc}
\hline Cation & $\mathbf{C}_{\mathbf{i}}(\mathbf{L} / \mathbf{m g})$ & Anion & $\mathbf{A}_{\mathbf{i}}(\mathbf{L} / \mathbf{m g})$ \\
\hline$\left[\mathrm{P}_{6,6,6,14}\right]^{+}$ & $6.23 \cdot 10^{-1}$ & {$[\mathrm{TFSI}]^{-}$} & $6.07 \cdot 10^{4}$ \\
{$\left[\mathrm{C}_{10} \mathrm{C}_{1} \mathrm{C}_{10} \mathrm{IM}\right]^{+}$} & $3.23 \cdot 10^{-1}$ & {$[\mathrm{DCA}]^{-}$} & $4.20 \cdot 10^{-1}$ \\
{$\left[\mathrm{C}_{12} \mathrm{C}_{1} \mathrm{IM}\right]^{+}$} & $3.23 \cdot 10^{-1}$ & {$[\mathrm{Cl}]^{-}$} & $2.18 \cdot 10^{-1}$ \\
{$\left[\mathrm{~N}_{8881}\right]^{+}$} & $1.54 \cdot 10^{-1}$ & {$\left[\mathrm{BEHP}^{-}\right.$} & $4.10 \cdot 10^{-2}$ \\
{$\left[\mathrm{~N}_{4441}\right]^{+}$} & $9.65 \cdot 10^{-2}$ & {$\left[\left(\mathrm{iC}_{8}\right)_{2} \mathrm{PO}_{2}\right]^{-}$} & $3.18 \cdot 10^{-2}$ \\
\hline
\end{tabular}

This table shows that the toxicity of the cationic part to E. coli descended as follows: $\left[\mathrm{P}_{6,6,6,14}\right]^{+}>$ $\left[\mathrm{C}_{10} \mathrm{C}_{1} \mathrm{C}_{10} \mathrm{IM}\right]^{+}=\left[\mathrm{C}_{12} \mathrm{C}_{1} \mathrm{IM}\right]^{+}>\left[\mathrm{N}_{8881}\right]^{+}>\left[\mathrm{N}_{4441}\right]^{+}$. Although the trend is very similar to that obtained in the bioluminescence tests, measuring toxicity to Vibrio fischeri, the values of $\mathrm{C}_{\mathrm{i}}$ for the $\left[\mathrm{P}_{6,6,6,14}\right]^{+}$cation were lower (approximately 1.6 times), and for the rest of the ILs the values were higher (around 2 times). This indicates that imidazolium and quaternary ammonium-based ILs were more toxic for Vibrio fischeri than for E. coli.

With respect to the toxicity of the anion, the trend was as follows: $[\mathrm{TFSI}]^{-}>[\mathrm{DCA}]^{-}>[\mathrm{Cl}]^{-}>[\mathrm{BEHP}]^{-}>$ $\left[\left(\mathrm{iC}_{8}\right)_{2} \mathrm{PO}_{2}\right]^{-}$. The value of $\mathrm{A}_{\mathrm{j}}$ was significantly higher for [TFSI]- than for the rest of the anions considered. These results are in agreement with those found by Bräutigam et al. [102], where the E. coli was deeply affected by the exposure to ILs based on [TFSI] anion. The rapid biosorption (adsorption plus bioaccumulation) of $[\mathrm{Cl}]^{-}$can explain its greater toxicity in comparison to $[\mathrm{BEHP}]^{-}$and $\left[\left(\mathrm{iC}_{8}\right)_{2} \mathrm{PO}_{2}\right]^{-}[2]$. Besides, the parameters $\mathrm{A}_{\mathrm{j}}$ for E. coli were higher than those estimated for Vibrio fischeri, which suggests that E. coli is more sensitive to the toxic stress produced by the ILs.

\subsection{Biodegradability evaluation}

\subsubsection{Biodegradability estimation}

Biodegradability under different conditions changes with the structure of the compound. Generally, an aromatic substituent (electron scavenger) increases the persistence of the chemical, possibly because enzymes find it harder to react with. However, functional groups such as carboxylic and amine among others, which 
are electron donors, usually produce a rise in the degree of biodegradability of the compound. The model called "Qualitative Substructure Model" has been developed by Niemi et al. [103] using a database of Biological Oxygen Demand (BOD) converted to average lifetimes. This means that a theoretical biological oxygen demand of $50 \%$ or higher obtained over a period of five days has a half-life $\left(\mathrm{t}_{1 / 2}\right.$, time necessary for $50 \%$ of the concentration to be eliminated) of five days, and that a theoretical BOD of $25 \%$, obtained over ten days, has a half-life of 20 days. Table 8 shows the results obtained.

Table 8. Estimation of the biodegradability through the qualitative model based on the substructure.

\begin{tabular}{|c|c|c|c|}
\hline Sample & Functional Group & $\begin{array}{c}\text { Estimated } \\
\text { biodegradability } \\
\left(\mathrm{t}_{1 / 2}\right) \\
\end{array}$ & Classification \\
\hline$\left[\mathrm{P}_{6,6,6,14}\right]\left[\left(\mathrm{iC}_{8}\right)_{2} \mathrm{PO}_{2}\right]$ & Highly branched structures & $>100$ & Persistent \\
\hline$\left[\mathrm{P}_{6,6,6,14}\right][\mathrm{BEHP}]$ & Highly branched structures & $>100$ & Persistent \\
\hline$\left[\mathrm{P}_{6,6,6,14}\right][\mathrm{TFSI}]$ & $\begin{array}{l}\text { Two halogen substitutions on an } \\
\text { unbranched, noncyclic structure } \\
\text { Highly branched structures }\end{array}$ & $>100$ & Persistent \\
\hline$\left[\mathrm{P}_{4,4,4,44}\right][\mathrm{DBS}]$ & $\begin{array}{c}\text { Benzene ring with }>2 \text { substitutions } \\
\text { Highly branched structures }\end{array}$ & $>100$ & Persistent \\
\hline$\left[\mathrm{P}_{4442}\right][\mathrm{DEP}]$ & - & - & Not applicable \\
\hline$\left[\mathrm{C}_{12} \mathrm{C}_{1} \mathrm{IM}\right][\mathrm{TFSI}]$ & $\begin{array}{l}\text { Two halogen substitutions on an } \\
\text { unbranched, noncyclic structure } \\
\text { Highly branched structures }\end{array}$ & $>100$ & Persistent \\
\hline$\left[\mathrm{N}_{4441}\right][\mathrm{TFSI}]$ & $\begin{array}{l}\text { Two halogen substitutions on an } \\
\text { unbranched, noncyclic structure } \\
\text { Highly branched structures }\end{array}$ & $>100$ & Persistent \\
\hline$\left[\mathrm{N}_{8881}\right][\mathrm{TFSI}]$ & $\begin{array}{l}\text { Two halogen substitutions on an } \\
\text { unbranched, noncyclic structure } \\
\text { Highly branched structures }\end{array}$ & $>100$ & Persistent \\
\hline$\left[\mathrm{C}_{10} \mathrm{C}_{1} \mathrm{C}_{10} \mathrm{IM}\right][\mathrm{TFSI}]$ & $\begin{array}{l}\text { Two halogen substitutions on an } \\
\text { unbranched, noncyclic structure } \\
\text { Highly branched structures }\end{array}$ & $>100$ & Persistent \\
\hline$\left[\mathrm{P}_{6,6,6,14}\right][\mathrm{DCA}]$ & Highly branched structures & $>100$ & Persistent \\
\hline$\left[\mathrm{N}_{4441}\right][\mathrm{DCA}]$ & - & - & Not applicable \\
\hline$\left[\mathrm{P}_{6,6,6,14}\right][\mathrm{Cl}]$ & Highly branched structures & $>100$ & Persistent \\
\hline
\end{tabular}




\begin{tabular}{clcc}
\hline ZDDP1 & Highly branched structures & $>100$ & Persistent \\
\hline ZDDP2 & Highly branched structures & $>100$ & Persistent \\
\hline
\end{tabular}

Using the above-mentioned model, the structural features associated with chemicals should be identified as biodegradable or persistent. It is important to notice that if the chemical does not have any biodegradable structure, the compound is classified as persistent. On the contrary, if the substance has essentially a biodegradable structure, in absence of any non-biodegradable element, the substance is classified as biodegradable. Therefore, the biodegradable classification is only used in absence of persistent elements. For those ILs whose chemical structures contain more than one functional group (two halogen substitutions, highly branched, etc), the estimated biodegradability $\left(t_{1 / 2}\right)$ is calculated by considering the most restrictive group. Chemical compounds that do not have any of these mentioned descriptors are considered as unclassifiable.

In view of the results obtained, it is not an easy task to extract interesting conclusions from the application of this model. Most of the ILs and ZDDPs here studied are highly branched, which implies a low biodegradability and high persistence ( $\mathrm{t}_{1 / 2}>100$ days). In addition, nothing can be said about $\left[\mathrm{P}_{4442}\right][\mathrm{DEP}]$ and $\left[\mathrm{N}_{4441}\right][\mathrm{DCA}]$ because they do not fit into any of the possible criteria. However, they could be expected to be more biodegradable than the rest of the samples, due to the absence of heterocycles, fluorine and large branches $[1,82]$.

\subsubsection{Biodegradability calculation}

Biodegradation can be defined as the assimilation of chemical compounds by microbes [83]. A quantitative description of the tendency of lubricant additives to undergo biodegradation is given in Table 9, which shows the biodegradability index $\left(\mathrm{BOD}_{5} / \mathrm{COD}\right)$ of the different aqueous solutions containing the ILs and the traditional lubricant additive. In all the studied ILs, it was found values of $\frac{B O D_{5}}{C O D}<0.3$, indicating that these compounds are poorly biodegradable [104-106]. Therefore, their carbon content is not a suitable carbon source for the microorganisms [107]. This fact can be explained due to the presence in the chemical structure of different elements such as halides, heterocycles, quaternary carbon atoms and high alkyl branching [108, 109]. In addition, literature research showed that rising the length of carbon side chains (until C10 - C11) 
should enhance biodegradation due to the presence of additional oxidizable carbons [110]. This may be the reason why the ILs here studied showed a $\mathrm{BOD}_{5} / \mathrm{COD}$ ratio slightly higher than those reported by Oliveira et al. [83], in which this ratio varied between 0.01 and 0.02 for short side chain $\left(\mathrm{C}_{4}\right)$ ILs. This fact makes complicated to establish a balance between biodegradability and toxicity with ionic liquids [1]. However, in view of the lower $\mathrm{BOD}_{5}$ values obtained with $[\mathrm{TFSI}]^{-}$anion, the presence of halides seems to affect biodegradability more significantly than the length of carbon side chains.

Table 9. Biodegradability index $\left(\mathrm{BOD}_{5} / \mathrm{COD}\right)$ of the studied additives ILs and ZDDPs.

\begin{tabular}{|c|c|c|c|}
\hline Sample & $\mathrm{COD}\left(\mathrm{mg} \mathrm{O}_{2} / \mathrm{L}\right)$ & $\mathrm{BOD}_{5}\left(\mathrm{mg} \mathrm{O}_{2} / \mathrm{L}\right)$ & $\mathrm{BOD}_{5} / \mathrm{COD}$ \\
\hline$\left[\mathrm{P}_{6,6,6,14}\right]\left[\left(\mathrm{iC}_{8}\right)_{2} \mathrm{PO}_{2}\right]$ & $824 \pm 3$ & $54.5 \pm 0.3$ & $0.070 \pm 0.010$ \\
\hline$\left[\mathrm{P}_{6,6,6,14}\right][\mathrm{BEHP}]$ & $758 \pm 4$ & $52.3 \pm 0.2$ & $0.070 \pm 0.010$ \\
\hline$\left[\mathrm{P}_{6,6,6,14}\right][\mathrm{TFSI}]$ & $605 \pm 1$ & $32.7 \pm 0.3$ & $0.050 \pm 0.010$ \\
\hline$\left[\mathrm{P}_{6,6,6,14}\right][\mathrm{DCA}]$ & $832 \pm 2$ & $51.6 \pm 0.2$ & $0.060 \pm 0.007$ \\
\hline$\left[\mathrm{P}_{6,6,6,14}\right][\mathrm{Cl}]$ & $824 \pm 2$ & $53.9 \pm 0.4$ & $0.065 \pm 0.009$ \\
\hline$\left[\mathrm{P}_{4,4,4,14}\right][\mathrm{DBS}]$ & $768 \pm 3$ & $58.1 \pm 0.5$ & $0.080 \pm 0.010$ \\
\hline$\left[\mathrm{P}_{4442}\right][\mathrm{DEP}]$ & $646 \pm 5$ & $46.4 \pm 0.4$ & $0.070 \pm 0.020$ \\
\hline$\left[\mathrm{C}_{12} \mathrm{C}_{1} \mathrm{IM}\right][\mathrm{TFSI}]$ & $472 \pm 2$ & $29.8 \pm 0.5$ & $0.060 \pm 0.020$ \\
\hline$\left[\mathrm{C}_{10} \mathrm{C}_{1} \mathrm{C}_{10} \mathrm{IM}\right][\mathrm{TFSI}]$ & $549 \pm 5$ & $36.7 \pm 0.2$ & $0.070 \pm 0.010$ \\
\hline$\left[\mathrm{N}_{8881}\right][\mathrm{TFSI}]$ & $290 \pm 4$ & $20.0 \pm 0.1$ & $0.060 \pm 0.020$ \\
\hline$\left[\mathrm{N}_{4441}\right][\mathrm{TFSI}]$ & $463 \pm 2$ & $31.0 \pm 0.1$ & $0.067 \pm 0.009$ \\
\hline$\left[\mathrm{N}_{4441}\right][\mathrm{DCA}]$ & $864 \pm 3$ & $66.5 \pm 0.5$ & $0.080 \pm 0.010$ \\
\hline ZDDP1 & $478 \pm 2$ & $20.5 \pm 0.1$ & $0.043 \pm 0.009$ \\
\hline ZDDP2 & $596 \pm 2$ & $16.0 \pm 0.1$ & $0.027 \pm 0.009$ \\
\hline
\end{tabular}

The traditional lubricant additive ZDDP (ZDDP1 and ZDDP2) were also poorly biodegradable, with $\mathrm{BOD}_{5} / \mathrm{COD}$ values lower than those observed in the ILs. These additives have very large molecular weights, which mean that they are not easily reachable to the microbes involved in degradation processes [111]. Various substituted imidazolium, phosphonium and quaternary ammonium derivatives have been screened for their biodegradability and, in general, they also exhibited low levels of biodegradation [77, 89, 110, 112-115]. Besides, it should be noted that most studies related to the evaluation of biodegradation have concluded that ionic liquids are compounds with low biodegradability $[116,117]$. 


\section{Conclusions}

In the ILs studied here, both the cationic and anionic parts exerted a significant effect on their toxicity to bacteria, although this was mainly determined by the cation. The $\left[\mathrm{P}_{6,6,6,14}\right][\mathrm{TFSI}]$ was found to be the most toxic IL for both Vibrio fischeri and E. coli, the $\mathrm{EC}_{50}$ values being $1.3 \pm 0.6 \mathrm{mg} / \mathrm{L}$ and $1.6 \pm 0.2 \mathrm{mg} / \mathrm{L}$, respectively, whereas the $\left[\mathrm{P}_{4442}\right][\mathrm{DEP}] \mathrm{IL}$ was the least toxic, with values of $55.2 \pm 0.7 \mathrm{mg} / \mathrm{L}$ and $39.1 \pm 0.6$ $\mathrm{mg} / \mathrm{L}$, respectively. This can be explained by the higher side chain length of the cation and the presence of fluorine in the anion. It should be noted that $E$. coli was more sensitive to the stress caused by the ILs, since the $\mathrm{EC}_{50}$ values were generally lower than those obtained with Vibrio fischeri. The $\mathrm{EC}_{50}$ values of the traditional lubricant additive (ZDDP1 and ZDDP2) were generally lower than $1.0 \pm 0.2 \mathrm{mg} / \mathrm{L}$ for both Vibrio fischeri and E. coli, showing the high toxicity of these compounds. The presence of zinc in their composition is most likely to be the main factor behind such toxicity.

In addition, all the ILs were poorly biodegradable, showing $\mathrm{BOD}_{5} / \mathrm{COD}$ values in the range of $0.05 \pm 0.01$ to $0.08 \pm 0.01$. This is due to the presence in their chemical structure of halides, heterocycles, alkyl chain branching or/and quaternary carbon that hinders biodegradability. ZDDP1 and ZDDP2 were also found to be poorly biodegradable with values between $0.043 \pm 0.009$ and $0.027 \pm 0.02$, respectively.

The excellent tribological properties as a lubricant additive shown by $\left[\mathrm{P}_{6,6,6,14}\right]\left[\left(\mathrm{iC}_{8}\right)_{2} \mathrm{PO}_{2}\right]$ and $\left[\mathrm{P}_{6,6,6,14}\right][\mathrm{BEHP}]$ in previous research, combined with their having better environmental properties than the traditional lubricant additive ZDDP, make these two ILs interesting candidates as partial or total replacements for this traditional additive. In this sense, the ease of combining different kinds of cations and anions in order to synthesize new ILs may also allow highly biodegradable ionic liquids with low toxicity to be found in the near future.

\section{Abbreviations}

$\left[\mathrm{P}_{6,6,6,14}\right]\left[\left(\mathrm{iC}_{8}\right)_{2} \mathrm{PO}_{2}\right] \quad$ Trihexyltetradecylphosphonium bis(2,4,4-trimethylpentyl) phosphinate

$\left[\mathrm{P}_{6,6,6,14}\right][\mathrm{BEHP}] \quad$ Trihexyltetradecylphosphonium bis(2-ethylhexyl)phosphate

$\left[\mathrm{P}_{6,6,6,14}\right][\mathrm{TFSI}] \quad$ Trihexyltetradecylphosphonium bis(trifluoromethylsulfonyl) imide

$\left[\mathrm{P}_{6,6,6,14}\right][\mathrm{DCA}] \quad$ Trihexyltetradecylphosphonium dicyanamide 


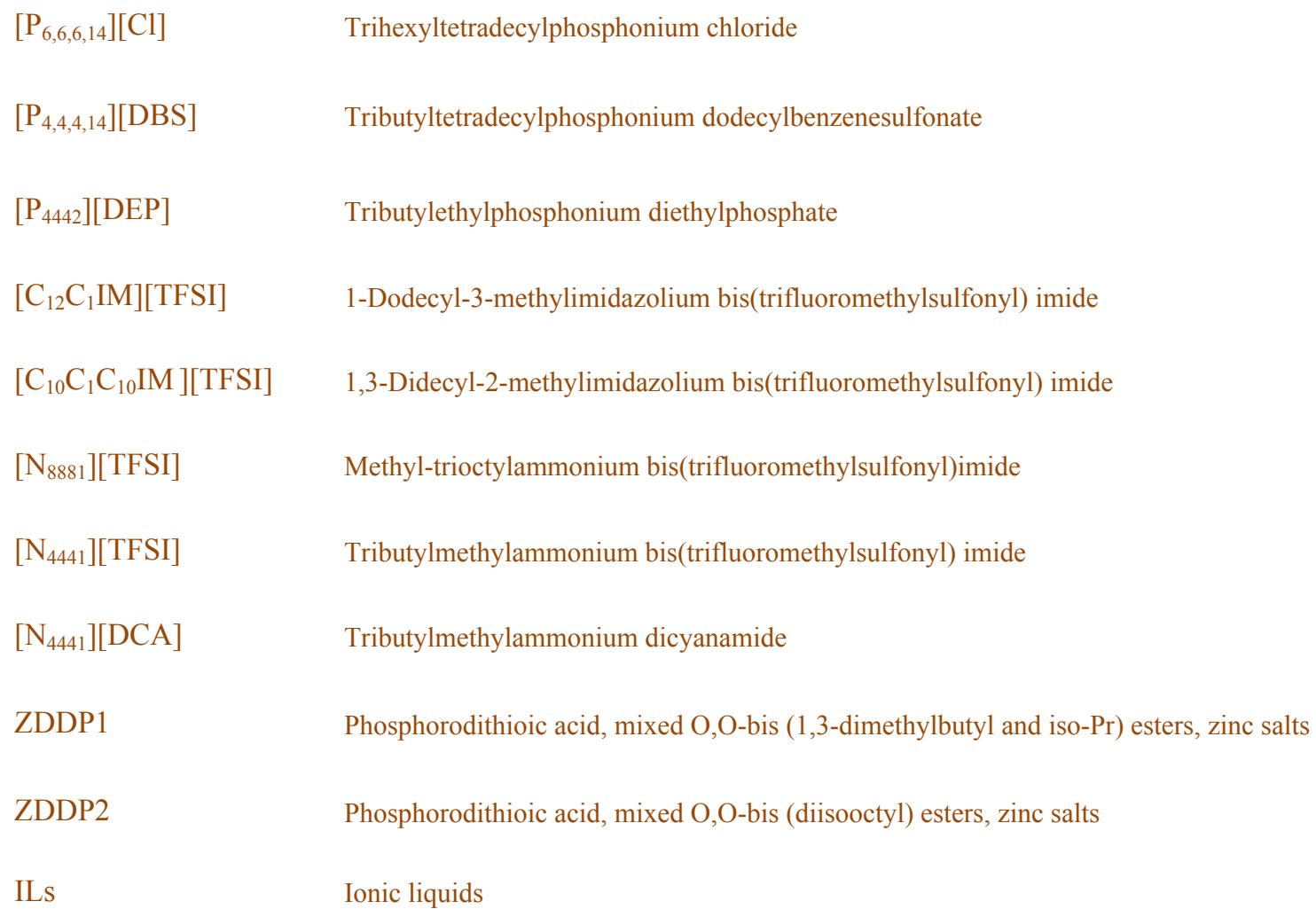

\section{Acknowledgments}

Authors would like to thank both the governments of Spain and the Principality of Asturias for supporting this research under the STARLUBE (DPI2013-48348-C2-1-R) and Lubrication and Surface Technology (GRUPIN14-023) projects, respectively.

\section{References}

[1] Costa SPF, Azevedo AMO, Pinto PCAG, Saraiva MLMFS. Environmental Impact of Ionic Liquids: Recent Advances in (Eco)toxicology and (Bio)degradability. ChemSusChem 2017;10:2321-47. doi:10.1002/cssc. 201700261 .

[2] Petkovic M, Seddon KR, Rebelo LPN, Silva Pereira C. Ionic liquids: a pathway to environmental acceptability. Chem Soc Rev 2011;40:1383-403. doi:10.1039/C004968A.

[3] Guo F, Zhang S, Wang J, Teng B, Zhang T, Fan M. Synthesis and applications of ionic liquids in clean energy and environment: A review. Curr. Org. Chem. 2015;19(5):455-68. doi:10.2174/1385272819666150114235649. 
[4] Zhou F, Liang Y, Liu W. Ionic liquid lubricants: Designed chemistry for engineering applications. Chem. Soc. Rev. 2009;38:2590-9. doi:10.1039/b817899m.

[5] Carda-Broch S, Berthod A, Angel MJR-. Ionic liquids in separation techniques. J. Chromatogr. A 2008;1184:6-18. doi:10.1016/j.chroma.2007.11.109.

[6] Olivier-Bourbigou H, Magna L, Morvan D. Ionic liquids and catalysis: Recent progress from knowledge to applications. Appl. Catal. A Gen. 2010;373:1-56. doi:10.1016/j.apcata.2009.10.008.

[7] Keskin S, Kayrak-Talay D, Akman U, Hortaçsu Ö. A review of ionic liquids towards supercritical fluid applications. J. Supercrit. Fluids 2007;43:150-80. doi:10.1016/j.supflu.2007.05.013.

[8] Xiao H. Ionic Liquid Lubricants: Basics and Applications. Tribol Trans 2016;2004:1-11. doi:10.1080/10402004.2016.1142629.

[9] Rensselar J Van. Unleashing the potential of ionic liquids. Tribol Lubr Technol 2010;April.

[10] Grzonkowska M, Sosnowska A, Barycki M, Rybinska A, Puzyn T. How the structure of ionic liquid affects its toxicity to Vibrio fischeri? Chemosphere 2016;159:199-207. doi:10.1016/j.chemosphere.2016.06.004.

[11] Ventura SPM, Marques CS, Rosatella AA, Afonso CAM, Gonçalves F, Coutinho JAP. Toxicity assessment of various ionic liquid families towards Vibrio fischeri marine bacteria. Ecotoxicol Environ Saf 2012;76:162-8. doi:10.1016/j.ecoenv.2011.10.006.

[12] Zhao D, Liao Y, Zhang ZD. Toxicity of ionic liquids. Clean - Soil, Air, Water 2007;35:42-8. doi:10.1002/clen.200600015.

[13] Salgado J, Parajó JJ, Teijeira T, Cruz O, Proupín J, Villanueva M, Rodríguez-Añón JA, Verdes PV, Reyes O. New insight into the environmental impact of two imidazolium ionic liquids. Effects on seed germination and soil microbial activity. Chemosphere 2017;185:665-72. doi:10.1016/j.chemosphere.2017.07.065.

[14] Neumann J, Steudte S, Cho C-W, Thöming J, Stolte S. Biodegradability of 27 pyrrolidinium, morpholinium, piperidinium, imidazolium and pyridinium ionic liquid cations under aerobic conditions. Green Chem 2014;16:2174-84. doi:10.1039/C3GC41997E. 
[15] Ma S, Lv M, Deng F, Zhang X, Zhai H, Lv W. Predicting the ecotoxicity of ionic liquids towards Vibrio fischeri using genetic function approximation and least squares support vector machine. J Hazard Mater 2015;283:591-8. doi:10.1016/j.jhazmat.2014.10.011.

[16] Costa SPF, Pinto PCAG, Lapa RAS, Saraiva MLMFS. Toxicity assessment of ionic liquids with Vibrio fischeri: An alternative fully automated methodology. J Hazard Mater 2015;284:136-42. doi:10.1016/j.jhazmat.2014.10.049.

[17] Montalbán MG, Hidalgo JM, Collado-González M, Díaz Baños FG, Víllora G. Assessing chemical toxicity of ionic liquids on Vibrio fischeri: Correlation with structure and composition. Chemosphere 2016;155:405-14. doi:10.1016/j.chemosphere.2016.04.042.

[18] Ghanem O Ben, Papaiconomou N, Abdul Mutalib MI, Viboud S, El-Harbawi M, Uemura Y, Gonfa G, Bustam MA, Leveque JM. Thermophysical properties and acute toxicity towards green algae and Vibrio fischeri of amino acid-based ionic liquids. J Mol Liq 2015;212:352-9. doi:10.1016/j.molliq.2015.09.017.

[19] Yan F, Shang Q, Xia S, Wang Q, Ma P. Topological study on the toxicity of ionic liquids on Vibrio fischeri by the quantitative structure-activity relationship method. J Hazard Mater 2015;286:410-5. doi:10.1016/j.jhazmat.2015.01.016.

[20] Peric B, Sierra J, Martí E, Cruañas R, Garau MA, Arning J, Bottin-Weber U, Stolte S. (Eco)toxicity and biodegradability of selected protic and aprotic ionic liquids. J Hazard Mater 2013;261:99-105. doi:10.1016/j.jhazmat.2013.06.070.

[21] Ye C, Liu W, Chen Y, Yu L. Room-temperature ionic liquids: a novel versatile lubricant. Chem Commun (Camb) 2001:2244-5. doi:10.1039/B106935G.

[22] Minami I. Ionic liquids in tribology. Molecules 2009;14:2286-305. doi:10.3390/molecules14062286.

[23] Bermúdez MD, Jiménez AE, Sanes J, Carrión FJ. Ionic liquids as advanced lubricant fluids. Molecules 2009;14:2888-908. doi:10.3390/molecules14082888.

[24] Palacio M, Bhushan B. A review of ionic liquids for green molecular lubrication in nanotechnology. Tribol Lett 2010;40:247-68. doi:10.1007/s11249-010-9671-8.

[25] Somers A, Howlett P, MacFarlane D, Forsyth M. A Review of Ionic Liquid Lubricants. Lubricants 2013;1:3-21. doi:10.3390/lubricants1010003. 
[26] Zhou Y, Qu J. Ionic Liquids as Lubricant Additives - a Review. ACS Appl Mater Interfaces 2016. doi:10.1021/acsami.6b12489.

[27] Jiménez AE, Bermúdez MD, Iglesias P, Carrión FJ, Martínez-Nicolás G. 1-N-alkyl -3methylimidazolium ionic liquids as neat lubricants and lubricant additives in steel-aluminium contacts. Wear 2006;260:766-82. doi:10.1016/j.wear.2005.04.016.

[28] Somers AE, Biddulph SM, Howlett PC, Sun J, MacFarlane DR, Forsyth M. A comparison of phosphorus and fluorine containing IL lubricants for steel on aluminium. Phys Chem Chem Phys 2012;14:8224. doi:10.1039/c2cp40736a.

[29] Qu J, Blau PJ, Dai S, Luo H, Meyer HM. Ionic Liquids as Novel Lubricants and Additives for Diesel Engine Applications. Tribol Lett 2009;35:181-9. doi:10.1007/s11249-009-9447-1.

[30] García A, González R, Hernández Battez A, Viesca JL, Monge R, Fernández-González A, Hadfield, M. Ionic liquids as a neat lubricant applied to steel-steel contacts. Tribol Int 2014;72:42-50. doi:10.1016/j.triboint.2013.12.007.

[31] Jiang D, Hu L, Feng D. Crown-type ionic liquids as lubricants for steel-on-steel system. Tribol Lett 2011; 41:417-24. doi:10.1007/s11249-010-9726-x.

[32] Hernández Battez A, Bartolomé M, Blanco D, Viesca JL, Fernández-González A, González R. Phosphonium cation-based ionic liquids as neat lubricants: Physicochemical and tribological performance. Tribol Int 2016; 95:118-31. doi:10.1016/j.triboint.2015.11.015.

[33] Zhang L, Feng D, Xu B. Tribological characteristics of alkylimidazolium diethyl phosphates ionic liquids as lubricants for steel-steel contact. Tribol Lett 2009; 34: 95-101. doi:10.1007/s11249-009-9412-z.

[34] Totolin V, Minami I, Gabler C, Dörr N. Halogen-free borate ionic liquids as novel lubricants for tribological applications. Tribol Int 2013; 67:191-8. doi:10.1016/j.triboint.2013.08.002.

[35] Otero I, López ER, Reichelt M, Fernández J. Friction and anti-wear properties of two tris(pentafluoroethyl) trifluorophosphate ionic liquids as neat lubricants. Tribol Int 2014; 70:104-11. doi:10.1016/j.triboint.2013.10.002.

[36] Hernández Battez A, González R, Viesca JL, Fernández-González A, Hadfield M. Lubrication of PVD coatings with ethyl-dimethyl-2-methoxyethylammonium tris(pentafluoroethyl)trifluorophosphate. Tribol Int 2013; 58:71-8. doi:10.1016/j.triboint.2012.10.001. 
[37] Hernández Battez A, Blanco D, Fernández-González A, Mallada MT, González R, Viesca JL. Friction, wear and tribofilm formation with a $\left[\mathrm{NTf}_{2}\right]$ anion-based ionic liquid as neat lubricant. Tribol Int 2016; 103: 73-86. doi: 10.1016/j.triboint.2016.06.038.

[38] González R, Hernández Battez A, Blanco D, Viesca JL, Fernández-González A. Lubrication of TiN, CrN and DLC PVD Coatings with 1-Butyl-1-Methylpyrrolidinium Tris(Pentafluoroethyl)Trifluorophosphate. Tribol Lett 2010; 40: 269-77. doi: 10.1007/s11249-010-9674-5.

[39] Blanco D, Battez AH, Viesca JL, González R, Fernández-González A. Lubrication of CrN coating with ethyl-dimethyl-2-methoxyethylammonium tris(pentafluoroethyl)trifluorophosphate ionic liquid as additive to PAO 6. Tribol Lett 2011; 41: 295-302. doi: 10.1007/s11249-010-9714-1.

[40] González R, Battez AH, Viesca JL, Higuera-Garrido A, Fernández-González A. Lubrication of DLC coatings with two tris(pentafluoroethyl)trifluorophosphate anion-based ionic liquids. Tribol Trans 2013; 56: 887-95. doi: 10.1080/10402004.2013.810319.

[41] Blanco D, González R, Hernández Battez A, Viesca JL, Fernández-González A. Use of ethyl-dimethyl-2methoxyethylammonium tris(pentafluoroethyl) trifluorophosphate as base oil additive in the lubrication of TiN PVD coating. Tribol Int 2011; 44: 645-50. doi: 10.1016/j.triboint.2011.01.004.

[42] Qu J, Bansal DG, Yu B, Howe JY, Luo HM, Dai S, Li HQ, Blau PJ, Bunting BG, Mordukhovich G, Smolenski DJ. Antiwear performance and mechanism of an oil-miscible ionic liquid as a lubricant additive. ACS Appl Mater Interfaces 2012; 4: 997- 1002. doi: 10.1021/am201646k.

[43] Wu J, Lu X, Feng X, Shi Y. Halogen-free ionic liquids as excellent lubricants for PEEK-stainless steel contacts at elevated temperatures. Tribol Int 2016;104:1-9. doi:10.1016/j.triboint.2016.08.009.

[44] Nainaparampil JJ, Eapen KC, Sanders JH, Voevodin AA. Ionic-liquid lubrication of sliding MEMS contacts: Comparison of AFM liquid cell and device-level tests. J Microelectromechanical Syst 2007;16:836-43. doi:10.1109/JMEMS.2007.901628.

[45] Qu J, Luo HM, Chi MF, Ma C, Blau PJ, Dai S, Viola MB. Comparison of an oil-miscible ionic liquid and ZDDP as a lubricant anti-wear additive. Tribol Int 2014; 71: 88-97. doi: 10.1016/j.triboint.2013.11.010.

[46] Qu J, Truhan JJ, Dai S, Luo H, Blau PJ. Ionic liquids with ammonium cations as lubricants or additives. Tribol Lett 2006;22:207-14. doi:10.1007/s11249-006-9081-0. 
[47] Viesca JL, García A, Hernández Battez A, González R, Monge R, Fernández-González A, Hadfield M. FAP- anion ionic liquids used in the lubrication of a steel-steel contact. Tribol Lett 2013;52:431-7. doi:10.1007/s11249-013-0226-7.

[48] González R, Bartolomé M, Blanco D, Viesca JL, Fernández-González A, Battez AH. Effectiveness of phosphonium cation-based ionic liquids as lubricant additive. Tribol Int 2016;98:82-93. doi:10.1016/j.triboint.2016.02.016.

[49] Hernández Battez A, Fernandes CMCG, Martins RC, Bartolomé M, González R, Seabra JHO. Two phosphonium cation-based ionic liquids used as lubricant additive. Part I: Film thickness and friction characteristics. Tribol Int 2017;107:233-9. doi:10.1016/j.triboint.2016.10.048.

[50] Hernández Battez A, Fernandes CMCG, Martins RC, Graça BM, Anand M, Blanco D, Seabra JHO. Two phosphonium cation-based ionic liquids used as lubricant additive. Part II: Tribofilm analysis and friction torque loss in cylindrical roller thrust bearings at constant temperature. Tribol Int 2017;109:496504. doi:10.1016/j.triboint.2017.01.020.

[51] Monge R, González R, Hernández Battez A, Fernández-González A, Viesca JL, García A, Hadfield M. Ionic liquids as an additive in fully formulated wind turbine gearbox oils. Wear 2015;328-329:50-63. doi:10.1016/j.wear.2015.01.041.

[52] Fernandes CMCG, Battez AH, González R, Monge R, Viesca JL, García A, Martins RC, Seabra JHO. Torque loss and wear of FZG gears lubricated with wind turbine gear oils using an ionic liquid as additive. Tribol Int 2015;90:306-14. doi:10.1016/j.triboint.2015.04.037.

[53] Anand M, Hadfield M, Viesca JL, Thomas B, Hernández Battez A, Austen S. Ionic liquids as tribological performance improving additive for in-service and used fully-formulated diesel engine lubricants. Wear 2015;334-335:67-74. doi:10.1016/j.wear.2015.01.055.

[54] Somers AE, Khemchandani B, Howlett PC, Sun J, Macfarlane DR, Forsyth M. Ionic liquids as antiwear additives in base oils: Influence of structure on miscibility and antiwear performance for steel on aluminum. ACS Appl Mater Interfaces 2013;5:11544-53. doi:10.1021/am4037614.

[55] Jiménez AE, Bermúdez MD. Imidazolium ionic liquids as additives of the synthetic ester propylene glycol dioleate in aluminium-steel lubrication. Wear 2008;265:787-98. doi:10.1016/j.wear.2008.01.009. 
[56] Yao MH, Liang YM, Xia YQ, Zhou F. Bisimidazolium ionic liquids as the high-performance antiwear additives in poly(ethylene glycol) for steel-steel contacts. ACS Appl Mater Interfaces 2009;1:467-71. doi:10.1021/am800132z.

[57] Cai MR, Liang YM, Yao MH, Xia YQ, Zhou F, Liu WM. Imidazolium ionic liquids as antiwear and antioxidant additive in poly(ethylene glycol) for steel/steel contacts. ACS Appl Mater Interfaces 2010;2:870-6. doi:10.1021/am900847j.

[58] Pejakovic V, Kronberger M, Mahrova M, Vilas M, Tojo E, Kalin M. Pyrrolidinium sulfate and ammonium sulfate ionic liquids as lubricant additives for steel/steel contact lubrication. Proc Inst Mech Eng Part J J Eng Tribol 2012;226:923-32. doi:10.1177/1350650112448978.

[59] Zhu L, Zhao Q, Wu X, Zhao G, Wang X. A novel phosphate ionic liquid plays dual role in synthetic ester oil: from synthetic catalyst to anti-wear additive. Tribol Int 2016; 97: 192-199. doi: 10.1016/j.triboint.2015.12.047.

[60] Jiménez AE, Bermúdez MD. Short alkyl chain imidazolium ionic liquid additives in lubrication of three aluminium alloys with synthetic ester oil. Tribol - Mater Surfaces Interfaces 2012;6:109-15. doi:10.1179/1751584X12Y.0000000011.

[61] Otero I, López ER, Reichelt M, Villanueva M, Salgado J, Fernández J. Ionic liquids based on phosphonium cations as neat lubricants or lubricant additives for a steel/steel contact. ACS Appl Mater Interfaces 2014;6:13115-28. doi:10.1021/am502980m.

[62] Gusain R, Gupta P, Saran S, Khatri OP. Halogen-free bis(imidazolium)/ bis(ammonium)di[bis(salicylato)borate] ionic liquids as energy-efficient and environmentally friendly lubricant additives. ACS Appl Mater Interfaces 2014; 6: 15318-28. doi: 10.1021/am503811t.

[63] Cai MR, Liang YM, Zhou F, Liu WM. A novel imidazolium salt with antioxidation and anticorrosion dual functionalities as the additive in poly(ethylene glycol) for steel/steel contacts. Wear 2012;306:197208. doi:10.1016/j.wear.2012.09.001.

[64] Khemchandani B, Somers A., Howlett P, Jaiswal A. K, Sayanna E, Forsyth M. A biocompatible ionic liquid as an antiwear additive for biodegradable lubricants. Tribol Int 2014;77:171-7. doi:10.1016/j.triboint.2014.04.016. 
[65] Qiao D, Wang HZ, Feng DP. Tribological performance and mechanism of phosphate ionic liquids as additives in three base oils for steel-on-aluminum contact. Tribol Lett 2014; 55:517-31. doi: 10.1007/s11249-014-0377-1.

[66] Blanco D, González R, Viesca JL, Fernández-González A, Bartolomé M, Hernández Battez A. Antifriction and antiwear properties of an ionic liquid with fluorine-containing anion used as lubricant additive. Tribol Lett 2017; 65:66. doi: 10.1007/s11249-017-0846-4.

[67] Gusain R, Dhingra S, Khatri OP. Fatty-Acid-Constituted Halogen-Free Ionic Liquids as Renewable, Environmentally Friendly, and High-Performance Lubricant Additives. Ind Eng Chem Res 2016;55:856-65. doi:10.1021/acs.iecr.5b03347.

[68] Pejakovic V, Tomastik C, Dörr N, Kalin M. Influence of concentration and anion alkyl chain length on tribological properties of imidazolium sulfate ionic liquids as additives to glycerol in steel-steel contact lubrication. Tribol Int 2016; 97: 234-243. doi: 10.1016/j.triboint.2016.01.034.

[69] Beran E. Experience with evaluating biodegradability of lubricating base oils. Tribol Int 2008;41:12128. doi:10.1016/j.triboint.2008.03.003.

[70] Luna FMT, Cavalcante JB, Silva FON, Cavalcante CL. Studies on biodegradability of bio-based lubricants. Tribol Int 2015;92:301-6. doi:10.1016/j.triboint.2015.07.007.

[71] Bartz WJ. Lubricants and the environment. Tribol Int 1998; 31: 35-47.

[72] Basu B, Singh M, Kapur G, Ali N, Sastry MI, Jain S, Srivastava S, Bhatnagar A. Prediction of biodegradability of mineral base oils from chemical composition using artificial neural networks. Tribol Int 1998; 31:159-168.

[73] Viesca JL, Mallada MT, Blanco D, Fernández-González A, Espina-Casado J, González R, Battez AH. Lubrication performance of an ammonium cation-based ionic liquid used as an additive in a polar oil. Tribol Int 2017;116:422-30. doi:10.1016/j.triboint.2017.08.004.

[74] Battez AH, Ramos D, Blanco D, González R, Fernández-González A, Viesca JL. Lubrication Properties of the Ionic Liquid Dodecyl - 3 Methylimidazolium bis (trifluoromethylsulfonyl) imide. Tribol Lett 2018:1-13. doi:10.1007/s11249-017-0964-Z.

[75] Blanco D, Hernández Battez, A, Fernández-González A, Viesca JL, Bartolomé M, González R. Friction and wear reduction properties of the tributyltetradecylphosphonium dodecylbenzenosulfonate ionic 
liquid used as lubricant additive. 21st International Conference on Wear of Materials, Long Beach, California (USA), March 26-30 2017.

[76] Blanco D, Bartolomé M, Fernández-González A, Viesca JL, González R, Hernández Battez A. Tribological behavior of two phosphonium cation-based ionic liquids used as lubricant additive un a polar oil. IX Iberian Conference on Tribology, University of Minho, Guimaraes (Portugal), June 12-13 ${ }^{\text {th }}$ 2017.

[77] Stolte S, Steudte S, Areitioaurtena O, Pagano F, Thoming J, Stepnowski P, Igartua A. Ionic liquids as lubricants or lubrication additives: An ecotoxicity and biodegradability assessment. Chemosphere 2012;89:1135-41. doi:10.1016/j.chemosphere.2012.05.102.

[78] Zhang S, Ma L, Wen P, Ye X, Dong R, Sun W, Fan M, Yang D, Zhou F, Liu W. The ecotoxicity and tribological properties of choline amino acid ionic liquid lubricants. Tribol Int 2018. doi:10.1016/j.triboint.2018.01.063.

[79] Development of Chemical Categories in the HPV Challenge Program: ZDDP category. The Health, Environmental, and Regulatory Task Group (HERTG) of the American Chemistry Council Petroleum Additives Panel. April 2005.

[80] APHA, AWWA and WEF. Standard Methods for Examination of Water and Wastewater, 21th ed., APHA, Washington, DC, 1999.

[81] ISO 11348-3, Water Quality - Determination of the Inhibitory Effect of Water Samples on the Light Emission of Vibrio fischeri (Luminescent Bacteria Test), International Standardization Organization, Geneva, 2007.

[82] Thuy Pham TP, Cho CW, Yun YS. Environmental fate and toxicity of ionic liquids: A review. Water Res 2010;44:352-72. doi:10.1016/j.watres.2009.09.030.

[83] Oliveira MVS, Vidal BT, Melo CM, de Miranda R de CM, Soares CMF, Coutinho JAP, Ventura SPM, Mattedi S, Lima ÁS. (Eco)toxicity and biodegradability of protic ionic liquids. Chemosphere 2016;147:460-6. doi:10.1016/j.chemosphere.2015.11.016.

[84] Thompson KC, Wadhia K, Loibner AP. Environmental Toxicity testing, 1st ed., Blackwell publishing, CRC Press, UK, 2005. 
[85] Chang SC, Wang YF, You SJ, Kuo YM, Tsai CH, Wang LC, Hsu PY. Toxicity evaluation of fly ash by Microtox ${ }^{\circledR}$. Aerosol Air Qual Res 2013;13:1002-8. doi:10.4209/aaqr.2012.10.0267.

[86] Alonso S, Rendueles M, Díaz M. Physiological heterogeneity of Pseudomonas taetrolens during lactobionic acid production. Appl. Microbiol. Biotechnol. 2012, 96(6), 1465-1477. Doi: $10.1007 / \mathrm{s} 00253-012-4254-2$.

[87] Chow W, Brocksen RW, Wisniewski J. Clean Water: Factors that influence its availability, quality and its use. International Clean Water Conference. California, 1995.

[88] Couling DJ, Bernot RJ, Docherty KM, Dixon JK, Maginn EJ. Assessing the factors responsible for ionic liquid toxicity to aquatic organisms via quantitative structure-property relationship modeling. Green Chem 2006;8:82-90. doi:10.1039/B511333D.

[89] Stolte S, Matzke M, Arning J, Böschen A, Pitner WR, Welz-Biermann U, Jastorff B, Ranke J. Effects of different head groups and functionalised side chains on the aquatic toxicity of ionic liquids. Green Chem 2007; 9: 1170-1179.

[90] Romero A, Santos A, Tojo J, Rodríguez A. Toxicity and biodegradability of imidazolium ionic liquids. J Hazard Mater 2008;151:268-73. doi:10.1016/j.jhazmat.2007.10.079.

[91] Luis P, Ortiz I, Aldaco R, Irabien A. A novel group contribution method in the development of a QSAR for predicting the toxicity (Vibrio fischeri EC50) of ionic liquids. Ecotoxicol Environ Saf 2007;67:4239. doi:10.1016/j.ecoenv.2006.06.010.

[92] Ranke J, Mölter K, Stock F, Bottin-Weber U, Poczobutt J, Hoffmann J, Ondruschka B, Filser J, Jastorff, B. Biological effects of imidazolium ionic liquids with varying chain lengths in acute Vibrio fischeri and WST-1 cell viability assays. Ecotoxicol Environ Saf 2004;58:396-404. doi:10.1016/S01476513(03)00105-2.

[93] Petkovic M, Ferguson JL, Gunaratne HQN, Ferreira R, Leitão MC, Seddon KR, Rebelo LPN, Pereira CS. Novel biocompatible cholinium-based ionic liquids - toxicity and biodegradability. Green Chem 2010;12:643. doi:10.1039/b922247b.

[94] Matzke M, Arning J, Ranke J, Jastorff B, Stolte S. Design of Inherently Safer Ionic Liquids: Toxicology and Biodegradation. Handbook of Green Chemistry. Wiley VCH Verlag GmbH \& Co. KGaA, 2010. 
[95] Tsiridis V, Petala M, Samaras P, Hadjispyrou S, Sakellaropoulos G, Kungolos A. Interactive toxic effects of heavy metals and humic acids on Vibrio fischeri. Ecotoxicol Environ Saf 2006;63:158-67. doi:10.1016/j.ecoenv.2005.04.005.

[96] UN/SCEGHS/12/IN.F.5, Sub-Committee of Experts on the Globally Harmonized System of classification and labelling of chemicals (GHS), United Nations, New York and Geneva, 2007.

[97] Globally Harmonized System of classification and labelling of chemicals (GHS), 4th revised edn, United Nations, New York and Geneva, 2011.

[98] Díaz, M., Herrero, M., García, L.A. and Quirós, C. Application of flow cytometry to industrial microbial bioprocesses. Biochem. Eng. J. 2010, 48(3), 385-407. Doi: 10.1016/j.bej.2009.07.013

[99] Grzonkowska M, Sosnowska A, Barycki M, Rybinska, A, Puzyn, T. How the structure of ionic liquid affects its toxicity to Vibrio fischeri? Chemosphere (2016); 159: 199-207. DOI: 10.1016/j.chemosphere.2016.06.004.

[100] Cieniecka-Roslonkiewicz A, Pernak J, Kubis-Feder J, Ramani A, Robertson AJ, Seddon KR. Synthesis, anti-microbial activities and anti-electrostatic properties of phosphonium-based ionic liquids. Green Chem 2005; 7(12): 855-862. 10.1039/B508499G.

[101] Babich H and Stotzky G. Toxicity of zinc to fungi, bacteria, and coliphages: influence of chloride ions. App and Environ Microb 1978; 36 (6): 906-914.

[102] Bräutigam S, Bringer-Meyer S, Weuster-Botz D. Asymmetric whole cell biotransformations in biphasic ionic liquid/water-systems by use of recombinant Escherichia coli with intracellular cofactor regeneration. Tetrahedron: Asymmetry 2007; 18(16): 1883-1887. doi.org/10.1016/j.tetasy.2007.08.003

[103] Niemi, GJ, Veith, GD, Regal RR, Vaishnav DD. Structural features associated with degradable and persistent chemicals. Environ Toxic Chem1987; 6:515-527. 10.1002/etc.5620060704.

[104] Gomes AC, Silva L, Simões R, Canto N, Albuquerque A. Toxicity reduction and biodegradability enhancement of cork processing wastewaters by ozonation. Water Sci. Technol. 2013; 68(10): 22142219. DOI: $10.2166 /$ wst.2013.478

[105] Acero JL, Benitez FJ, Heredia JB, Leal, AI. Chemical treatment of cork-processing wastewaters for potential reuse. J. Chem. Technol. Biotechnol. 2004; 79(10): 1065-1072. DOI:10.1002/jctb.1067 
[106] Peres JA, Beltrán de Heredia J, Domínguez, JR. Integrated Fenton's reagent-coagulation/flocculation process for the treatment of cork processing wastewaters. J. Hazard. Mater. 2004; 107(3): 115-121. DOI:10.1016/j.jhazmat.2003.09.012

[107] Srinivas TR. Environmental Biotechnology, New Age International Publishers, 1st edition, 2008.

[108] Boethling RS, Howard PH, Meylan W, Stiteler W, Beauman J, Tirado N. Group contribution method for predicting probability and rate of aerobic biodegradation. Environ Sci \& Tech 1994; 28(3): 459-465. DOI: $10.1021 / \mathrm{es} 00052 \mathrm{a} 018$.

[109] Howard PH, Boethling RS, Stiteler W, Meylan W, Beauman J. Development of a predictive model for biodegradability based on BIODEG, the evaluated biodegradation data base. Sci of The Tot Environ 1991; 109-110(Supplement C): 635-641. DOI:10.1016/0048-9697(91)90216-2.

[110] Atefi F, Garcia MT, Singer RD, Scammells PJ. Phosphonium ionic liquids: design, synthesis and evaluation of biodegradability. Green Chem 2009; 11(10): 1595-1604. DOI: 10.1039/B913057H.

[111] Madanhire I, Ignatio, C. Mbohwa, Mitigating Environmental Impact of Petroleum Lubricants. Chapter 2: Lubricant Additive Impacts on Human Health and the Environment. Springer International Publishing, Switzerland, 2016

[112] Thu HBT, Markiewicz M, Thoming J, Reich RM, Korinth V, Cokoja M, Kuhn FE, Stolte S. Catalytically active perrhenate based ionic liquids: a preliminary ecotoxicity and biodegradability assessment. New Journal of Chem 2015; 39(7): 5431-5436. Doi: 10.1039/C5NJ00404G.

[113] Žgajnar Gotvajn A, Tratar-Pirc E, Bukovec P, Žnidaršič Plazl P. Evaluation of biotreatability of ionic liquids in aerobic and anaerobic conditions. Water Sci and Tech 2014; 70(4): 698-704. DOI: 10.2166/wst.2014.283.

[114] Wells AS, Coombe VT. On the Freshwater Ecotoxicity and Biodegradation Properties of Some Common Ionic Liquids. Organic Process Research \& Development 2006; 10(4): 794-798. DOI: 10.1021/op060048i.

[115] Gathergood N, Garcia MT, Scammells PJ. Biodegradable ionic liquids: Part I. Concept, preliminary targets and evaluation. Green Chem 2004; 6(3): 166-175. 10.1039/B315270G.

[116] Jordan A, Gathergood N. Biodegradation of ionic liquids - a critical review. Chem Soc Reviews 2015; 44(22): 8200-8237. Doi: 10.1039/C5CS00444F. 
[117] Coleman D, Gathergood N. Biodegradation studies of ionic liquids. Chem Soc Reviews 2010; 39(2): 600-637. Doi: 10.1039/B817717C. 


\section{$\underline{\text { Highlights }}$}

- Both cation and anion have significant effect on toxicity.

- ZDDP samples were the most toxic ones for both $V$. fischeri and E. coli.

- E. coli was more sensitive to stress conditions induced by ILs than $V$. fischeri.

- The presence of halides and the length of the alkyl chain increase toxicity.

- Detrimental factors for biodegradability are branched alkyl chains and fluorine. 


\section{Graphical abstract}

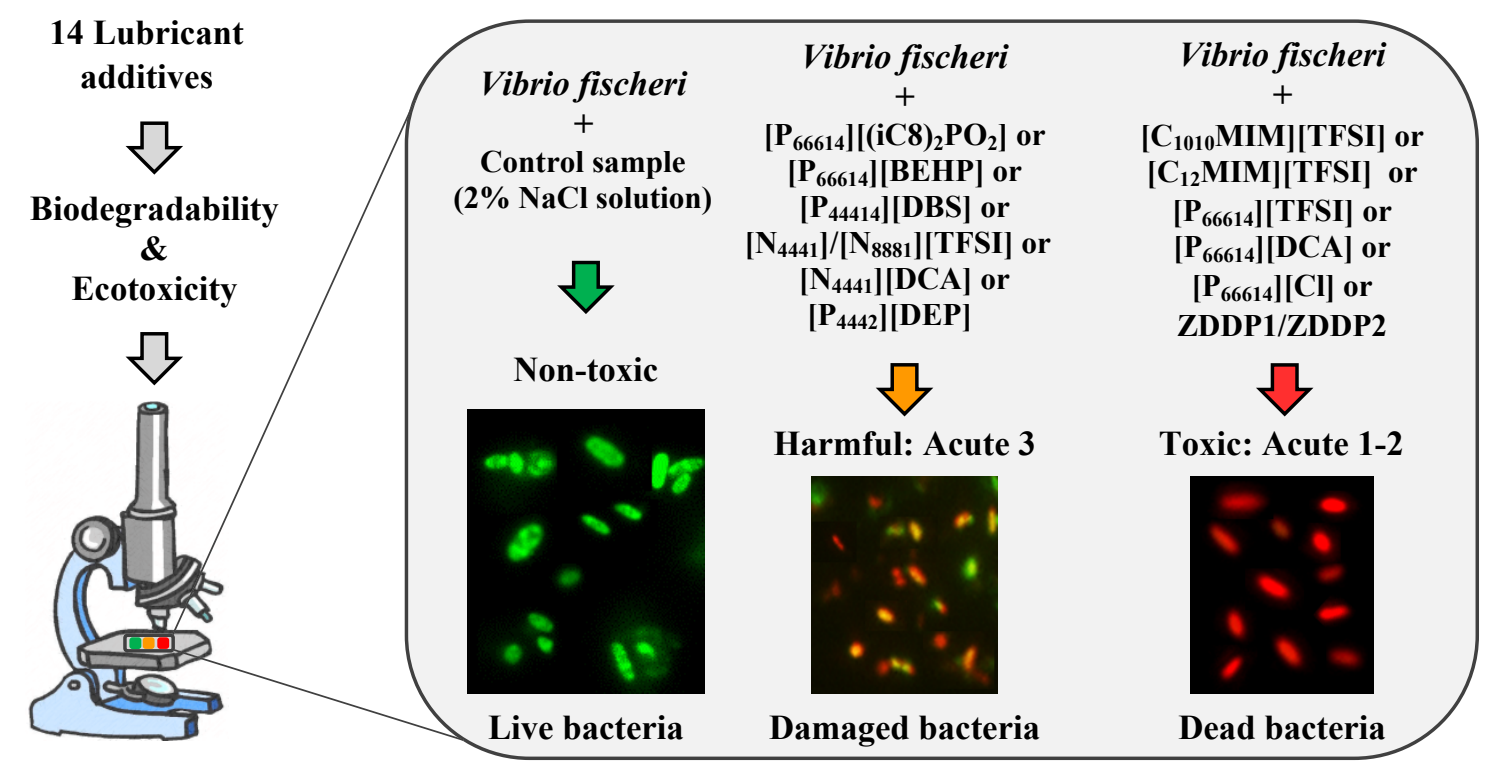

